\title{
A Maros Megyei Múzeum szerepe, kutatásai és tárgyi hagyatéka
}

SOÓS ZOLTÁN

$\mathbf{M}$ aros megye az I968-as román közigazgatási újjászervezés eredményeként jött létre, kiterjedése 6696 négyzetkilométer, lakossága megközelítőleg 530 ezer fó, amelyből 200 ezer magyarnak vallotta magát a 20I2-es népszámláláskor. Földrajzilag magában foglalja az erdélyi mezőség déli és keleti részét, illetve a Maros, Nyárád, Kis- és Nagy-Küküllő folyók völgyeit.

A magyarság fóleg a megye keleti és középső területein él tömbben, de szórványként szinte valamennyi község területén fellelhető. Kulturális hatása meghatározó jellegú a megye arculatát tekintve, kivéve az egykor szászok lakta déli Segesvárszéket. A Felső-Maros mente illetve a Mezőség többnyire román nemzetiségú, míg a Maros völgye vegyes román-magyar etnikumú, és számos kölcsönhatás figyelhető meg az építészettől a népmúvészetig. A megye létrehozása elsősorban a I960-as évek román szocialista nemzetiségpolitikájának köszönhető, amelynek elsődleges célja a Maros Magyar Autonóm Tartomány felszámolása volt. Az I968-ban létrehezott közigazgatási egység magában foglalta az egykori Marosszék területét (amelyhez néhány udvarhely- és keresztúrszéki falut csatoltak, pl. Bözöd, Magyarzsákod stb.), a történelmi Torda vármegye részeit (erdélyi Mezőség, Szászrégen, Görgény völogye), Kis-Küküllő vármegye részeit (Dicsőszentmárton, Radnót, Marosludas), illetve az egykori szászok lakta Nagy-Küküllő vármegye részeit (egykori Segesvárszék, Segesvár, Szászkézd) (I. kép).

Maros megye változatos etnikai és kulturális kisrégióvá vált, amely egyaránt magában foglalta a székely, magyar, szász, román kultúrát, illetve a polgári, falusi és nemesi életmódot. Magában foglalta az egykor kiváltságos székely és szász területek kultúráját, a hegyvidék román és székely lakosságának hagyományait, illetve a Mezőség és a Maros mente nemesi, illetve arisztokrata uradalmakkal tarkított életmódját. Mindez a sokszínúség fel- 


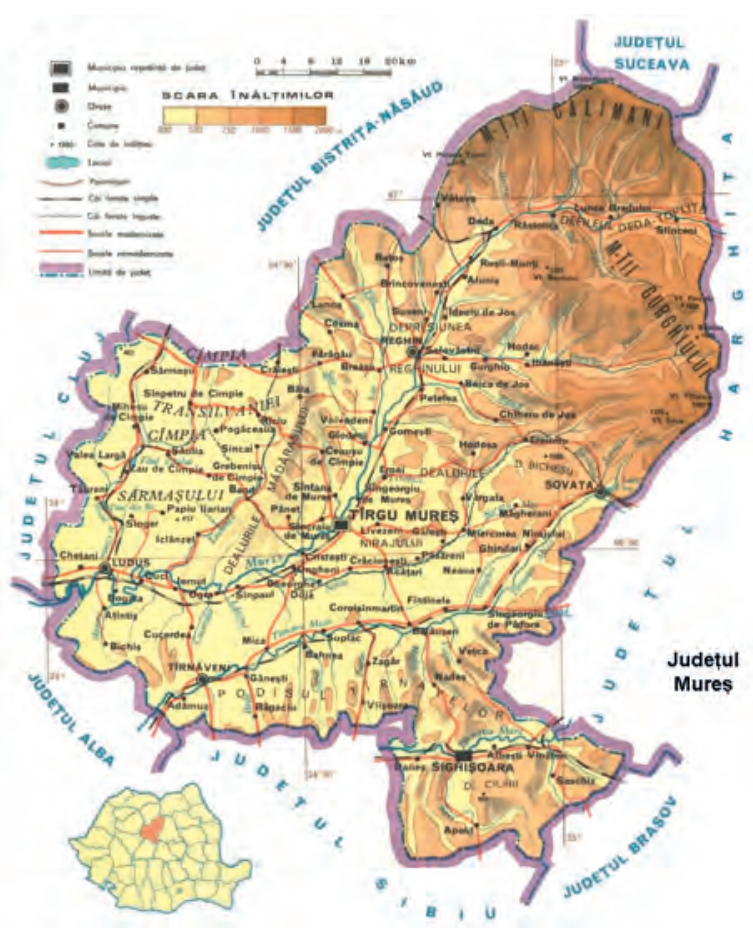

I. KÉP: Maros megye domborzati térképe

jogosít arra, hogy Maros megye kulturális örökségének tárgyalásakor bátran kijelenthessük, hogy ízelítőt kapunk Erdély szinte valamennyi kultúrájából.

A megye etnikai és kulturális gazdagságát érzékenyen érintette a szász lakosság exodusa, amely az 1970-es években vette kezdetét, és gyakorlatilag az ezredfordulóig szinte teljes mértékben eltúnt az Unio Trio Nationum egyik meghatározó eleme. A szász lakosság elvándorlása pótolhatatlan veszteség Erdély számára, az általuk képviselt kultúra, népszokások, hagyományok nyolc évszázadon keresztül Erdély egyik legmeghatározóbb alkotóeleme volt.

Az 1968-ban újonnan létrehozott Maros megye kulturális örökségvédelmét a Maros Megyei Múzeum látta el. Ez az intézmény az egykori Maros Magyar Autonóm Tartomány múzeumának a jogfolytonosságát biztosította. A 1960-as évek kultúrpolitikájának megfelelően a marosvásárhelyi múzeum bábáskodott a gyergyói és csíki múzeumok létrehozásánál, számos leltári tárgyat átadván a kezdőgyújtemények létrehozásánál. Az I968-as megyésítéskor a marosvásárhelyi múzeum hatáskörébe új területek kerültek, mint 
Segesvár, Marosludas, Dicsőszentmárton vidéke, a tartomány egykori keleti feléből pedig létrehozták Hargita megyét.

$\mathrm{Az}$ újonnan létrejött Maros Megyei Múzeum szerkezetileg nem sokat változott az I990-es évek végéig, a gyújtésre általában kevés pénz jutott, mindössze néhány lelkes, felkészült szakembernek volt köszönhető (külön kiemelném Bónis Johanna, Gál Kornélia, Zrínyi András szerepét), hogy a meglévő állományok fennmaradtak, és a szúkös lehetőségek, illetve a hozzá nem értó vezetóség által támasztott akadályok mellett, ha kis mértékben is, de gyarapodott az állomány. Gyakorlatilag 2005-ig egy, a szocialista beidegződéseket követő vezetősége volt a múzeumnak (1990 és 2005 között az egykori múzeumi párttitkár az igazgató), amely nem fejlesztette az intézményt, és a pénzhiányra hivatkozva az állománygyarapítás, tárgyvásárlás vagy a kutatás takaréklángra volt állítva. A múzeum épületeinek állaga leromlott, az állományok tárolási körülményei pedig szúkösek és elavultak voltak. Természetesen nem egy helyi jelenségről beszélünk, ugyanis a romániai múzeumok jelentős része elavult intézmény, és a Maros Megyei Múzeum még a múködőként számon tartott intézmények közé számított. A rendszerváltás után a kisebb múzeumok jelentős része elsorvadt, hiszen szerepük egykor elsősorban a helyi pártpropaganda kiszolgálása, kiegészítése volt (lásd Medgyes, Dicsőszentmárton, Nagyenyed múzeumai).

A nagyobb múzeumok hasonló meghatározott céllal múködtek: a pártproganda eszközei voltak, a szocialista nacionalizmus ideológiáját népszerúsítették. Szatmártól Konstancáig jellegében ugyanaz a kiállítás volt látható, a kontinuitás sulykolása (ugyanazok a dák várak, római erődök). A középkor Gelu vajda, Hunyadi János - Iancu de Hunedoara, Matei Corvin!, azaz Corvin Máté Mátyás helyett, Vitéz Mihály stb. személyekre összpontosított, az egyetlen vezérelv a román nemzet ósiségének és dominanciájának a bizonyítása volt, amely sajnos napjainkig érezteti hatását, hiszen a hivatalos álláspont továbbra sem szakított ezekkel az elavult ideológiákkal. A nagy intézményeknél a jelentősebb létszám miatt valódi szakemberek is felvételre kerültek, kisebb intézményeknél ez változó volt a vezetőségtől függően. A legnagyobb kárt az ideológiai képzésre való túlzott hangsúly miatt a valós szakemberek hiánya jelentette, és a gyújtemények hibás kezelése. Ezt tetézte a kilencvenes évek elejének egyik legtragikusabb döntése a mútárgyak szempontjából, az örökségvédelmi törvény eltörlése. Az új örökségvédelmi törvény 1997-ben keletkezett, de a közel hétéves ex lex állapot a múkincsrablás kedvelt célpontjává tette Romániát. Teherautók tucatjaival exportálták az olcsón felvásárolt, még magánkézen levő múkincseket. A szakemberhiány a közgyújteményeket is szabad prédává változtatta, számos múkincslopás 
történt a gyakorlatilag felelős kezelő nélküli állományokból, amelyek jelentős része az elavult nyilvántartások miatt még csak ezután válik nyilvánvalóvá. Több tízezer mútárgy hagyta el nyom nélkül az országot, amelyek egy része különféle európai aukciósházakban időnként felbukkan.

A rendszerváltás 25 éve után továbbra is lassú a változás, és a legtöbb esetben a helyi politikai erőviszonyok függvénye, hogy ki kerül egy-egy intézmény élére. Természetesen a helyzet sokat javult a kommunizmus korszakához viszonyítva, hiszen már bizonyos szakmai kritériumoknak eleget kell tenni egy múzeum irányításához. Székelyföld tekintetében kifejezetten biztató a helyzet, a legtöbb intézmény élén fiatal, szakképzett kutatók állnak, és az intézményépítés és -fejlesztés komoly lendületet vett.

A Maros Megyei Múzeum jelenleg IOI munkatárssal és tíz szakosztálylyal rendelkezik: történelem, régészet, múvészet, néprajz, természetrajz, Görgény- és limes-kutató részleg, restaurálás, Kultúrpalota, adminisztráció, számítástechnika. A múzeum jelentős ingatlanállományt kezel, amelynek a karbantartása és restaurálása jelentős többletterhet jelent, ugyanakkor komoly felelősséggel jár. Összesen hat jelentős épület fenntartását és karbantartását végzi intézményünk, amelyek közül a legjelentősebb a magyar szecesszió egyik legszebb épülete, a Kultúrpalota, de szintén nagyon fontos a néprajzi gyújteménynek helyt adó Toldalagi-palota, az egykori várparancsnokság épületében múködő történelmi és régészeti múzeum, az egykori Székely Iparmúzeum épületében múködő természetrajzi részleg vagy a görgényszentimrei Rákóczi-Bornemissza-kastély. A múzeum hatodik épülete, egy, az 1970-es években épült egykori iskolai bentlakás, amelyet többéves munkával újítottunk fel, és ebben az épületben alakítottuk ki a raktárakat, könyvtárat, irodákat, restaurálómúhelyeket és a titkárság-könyvelőséget. Ez az értékes épületállomány egészült ki 2017 novemberében a mezőzáhi Ugron-kastély épületével (2. kép), amely korábban árvaházként múködött, majd 2008 óta kihasználatlanul állt.

\section{Épületek}

\section{KULTÚRPALOTA (1911-1913). \\ SZÉPMUUVÉSZETI GYÚJTEMÉNY}

A múzeum kezelésében levő épületek közül a legjelentősebb a Kultúrpalota, amely a magyar szecesszió egyik legkiemelkedőbb alkotása. A palota I9III9I3 között épült Komor Marcell és Jakab Dezső budapesti építészek tervei szerint. Különlegességét az újszerú formák és terek mellett az épület külső 


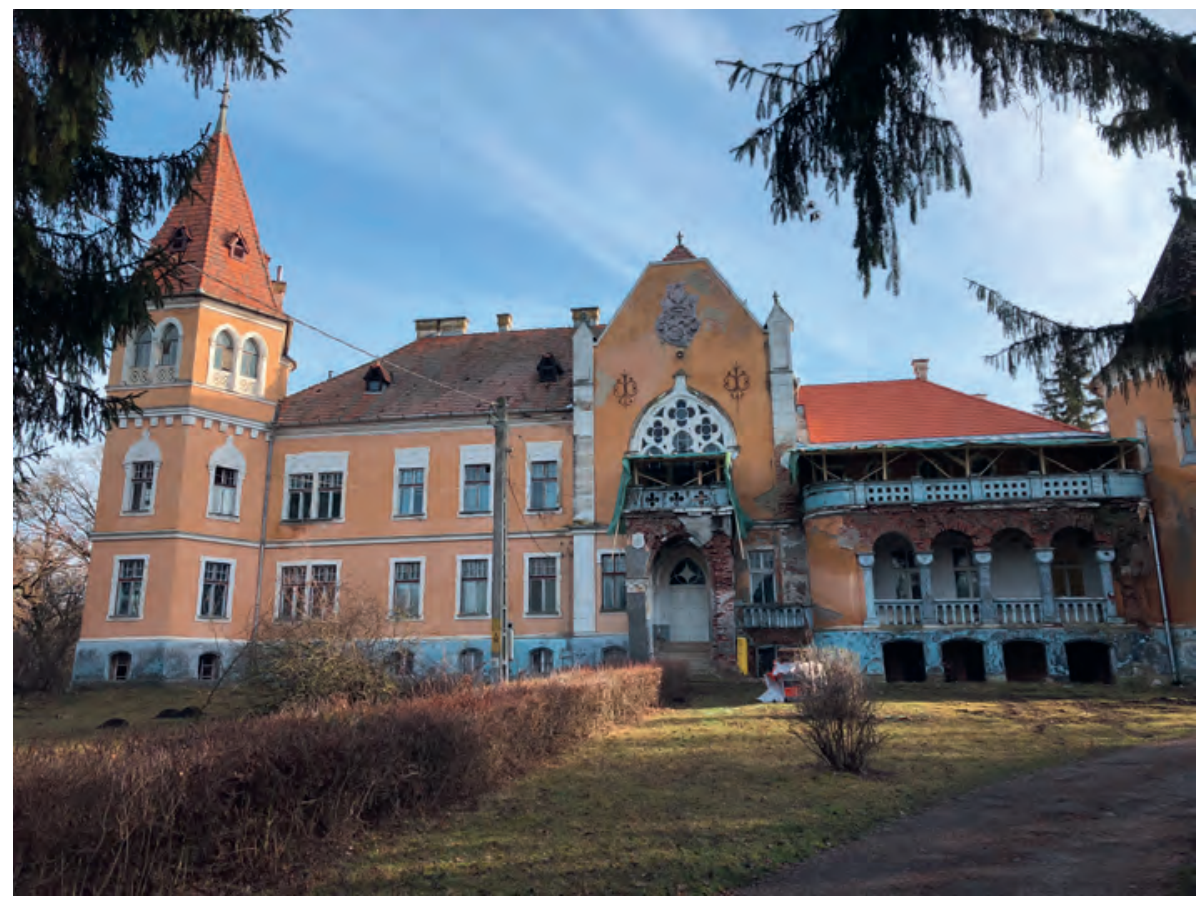

2. KÉP: A mezőzáhi Ugron-kastély

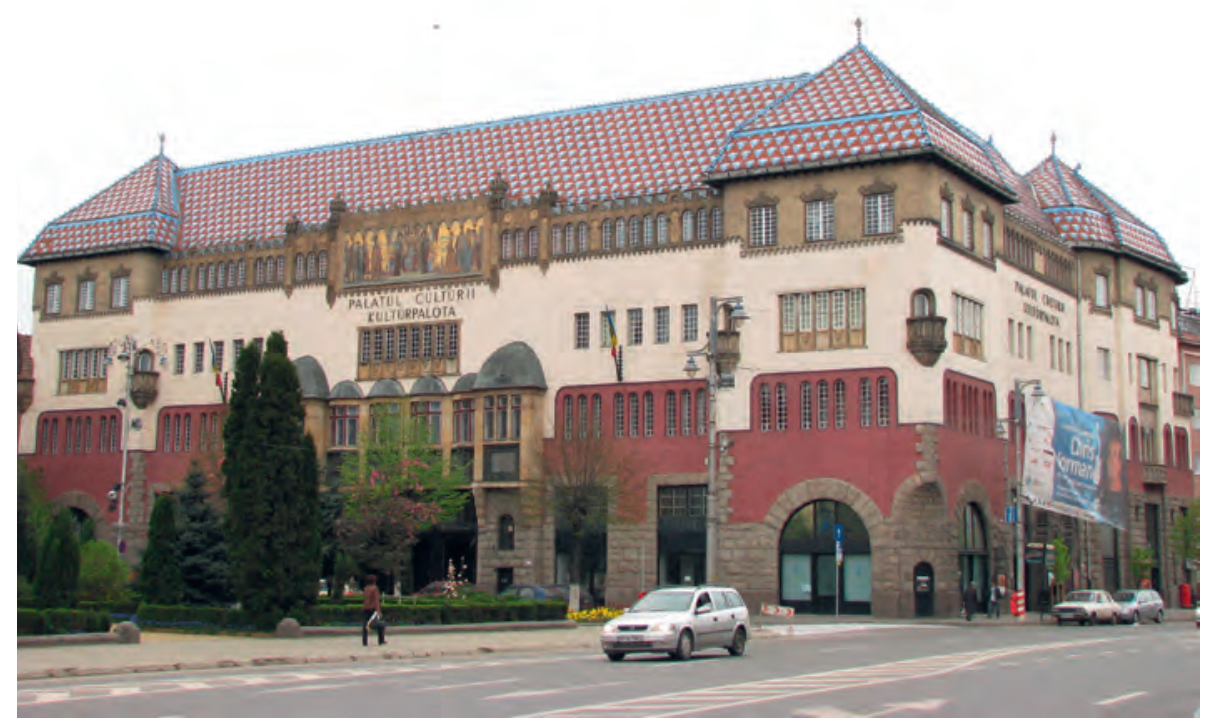

3. KÉP: A marosvásárhelyi Kultúrpalota 
és belső díszítése adja, amelyet a Marosvásárhelyre meghívott gödöllői múvésztelep modernista, preraffaelita stílusban alkotó múvészei díszítenek. A magyar szecesszió vívmányaként emlegetett Kultúrpalota a KomorJakab-építészpáros egyik legbravúrosabb tervének tekinthetó (3. kép).

„A saroktelken álló épület különböző funkcióinak szétválasztása, egyben összekapcsolása komoly feladatot jelentett. Az épület szíve a díszterem (hangversenyterem), mely a karzatokkal együtt három szint magasságot is átfog. A földszinten kéthajós előcsarnok húzódik előtte, az előcsarnok felett az első emeleten a tükörterem, a második emeleten a kis előadóterem található. A harmadik szintet teljes egészében a múzeum foglalta el. A hangversenyteremtől jobbra és balra a közlekedőterek - impozáns lépcsőházak - és a próbatermek, öltözők, kiszolgálóterek stb. találhatók. A szuterén szinten egykor hangulatos kávézó volt. A többszintes könyvtár az épülettől balra, háromszögletú térrel, modern konstrukciójú lépcsőházzal kapcsolódik a Kultúrpalota tömbjéhez. Az architektúra kialakítása Komor és Jakab múve, de az épület ikonográfiai programján és külső-belső díszítésén elsősorban nem ők, hanem a gödöllői múvésztelep tagjai dolgoztak. Annak érdekében, hogy a közmúvelődési ház a magyar képző- és iparmúvészet kincsesháza legyen - ahogyan az elhangzott az avatóbeszédben -, Bernády György polgármester a képző-, ipar- és zenemúvészek egész seregével személyesen tárgyalt.

Feltehetően Körösfői-Kriesch Aladárral (I863-1920) közösen dolgozták ki az ikonográfiai programot, az építészek pedig megteremtették mindennek a keretét. Az architektúra feladata volt, hogy összefogja és ellensúlyozza a számtalan, formailag és anyagában is különböző részletet.

$\mathrm{Az}$ épület kiegyensúlyozott, zárt tömegét a sarkokon rizalitok tagolják. A különböző falburkolatokkal horizontálisan jól elkülönített felületeket tagozatok, szobrok, dombormúvek, a tükörterem zárt erkélyeinek íves üvegmezői teszik mozgalmassá. A lábazati részt - akárcsak a városházán - faragott kváderek hangsúlyozzák. Ezek keretezik a bejárati ajtókat is, melyek modern vas-üveg konstrukciójukkal, fekete gránit borításukkal a bécsi szecessziós építészetet idézik. A négy bejárati ajtó fölött, a homlokzatból a tükörterem színes üvegablakos zárterkélyei domborodnak ki. Alattuk Kallós Ede bronzreliefjei a magyar zenetörténet igen jelentős alkotásának, Liszt Ferenc Szent Erzsébet legendája címú oratóriumának egyik képét, a Marosvásárhelyen élt, nemzetközi hírú két matematikus, Bolyai Farkas és Bolyai János alakját, a szintén Marosvásárhelyen élt író és erdélyi múvelődésszervező Aranka Györgyöt és az első Erdélyi Magyar Nyelvmívelő Társaság megalapítását, valamint a magyar szabadságtudat szempontjából is 
igen jelentős opera részletét, Erkel Ferenc Bánk bánjából Melinda drámai tettét jelenítik meg." 1

„A tető játékosan vibráló színeivel, a Zsolnay gyárban készült mázas (kék-fehér) és mázatlan (vörös) cserepekkel szintén az épület tömbszerúségét igyekszik feloldani. A magyar múvelődés marosvásárhelyi palotájának célkitúzését a főhomlokzat közepén ívsoros záródású, fekvő téglalap alakú mezőben elhelyezett, Körösfői-Kriesch Aladár által tervezett mozaikkép $(920 \times 320 \mathrm{~cm})$, A magyar kultúra apoteózisa (Hódolat Hungária előtt) summázza. A mozaikot Róth Miksa múhelye kivitelezte - akárcsak az oldalhomlokzati bejárat felett elhelyezett, zenei allegóriákat ábrázoló képeket is. Hungária allegorikus figurája a magyar királyi jelvényekkel ékesen (korona, koronázási palást, kard) trónol. A mozaikkép jól tükrözi Bernády György polgármester elképzelését, hogy Marosvásárhely, Székelyföld fóvárosaként, az erdélyi múvelődés fellegvárával, Kolozsvárral egyenrangú félként vegyen részt a magyar kultúra apoteózisában. $S$ mint ahogy házavató beszédében arra többször is utalt a polgármester, az épület külső megjelenítésének is az erdélyi magyar kultúra fölényét és nagyságát kellett tükröznie. Ez a magyar kultúra nagyjainak felvonultatásával és a Szent Korona védelme alatt trónoló Hungária alakjának központba helyezésével jut érvényre az épület föhomlokzatán." ${ }^{2}$

A belső terek kialakítása díszítése szintén nagy figyelemmel és igényességgel van kivitelezve, a keleties hatást tükröző pompás előcsarnok vagy a halványlila, bordó és aranyszínt harmonikusan ötvöző elegáns hangversenyterem a palota legjelentősebb terei. Az előcsarnok kialakítása Körösfói-Kriesch Aladár tervei szerint történt, a lépcsőházak gazdag népies jellegú díszítése Falus Elek munkáját dicsérik. Két kisebb rendezvényterem található az első és a második emeleten. A kisterem és a tükörterem szintén gazdag belső díszítéssel rendelkezik, de talán a palota leghíresebb múrészletei láthatóak itt, a Róth Miksa múhelyében készült és a magyar szecesszió legszebbjeként nyilvántartott üvegablakok (4-5. kép). Az üvegek Thoroczkai Wigand Ede és Nagy Sándor tervei alapján készültek. A tükörterem központi festett üvegablakain Budai Ilona, Kádár Kata, Júlia szép leány, Salamon Sára, erdélyi népballadák által ihletett jelenetek láthatók, a hat szélső üvegablakon néprajzi ihletésú belsők, illetve tájak láthatók. A kisterem üvegablakain Bethlen Gábort láthatjuk tudósai körében.

A Kultúrpalota 7500 négyzetméter hasznos felülettel rendelkezik, és

1 A Marosvásárhelyi Kultúrpalota. Szerk. Oniga Erika. Tipographic, Marosvásárhely, 2016. 32.

2 Uo. 35-36. 


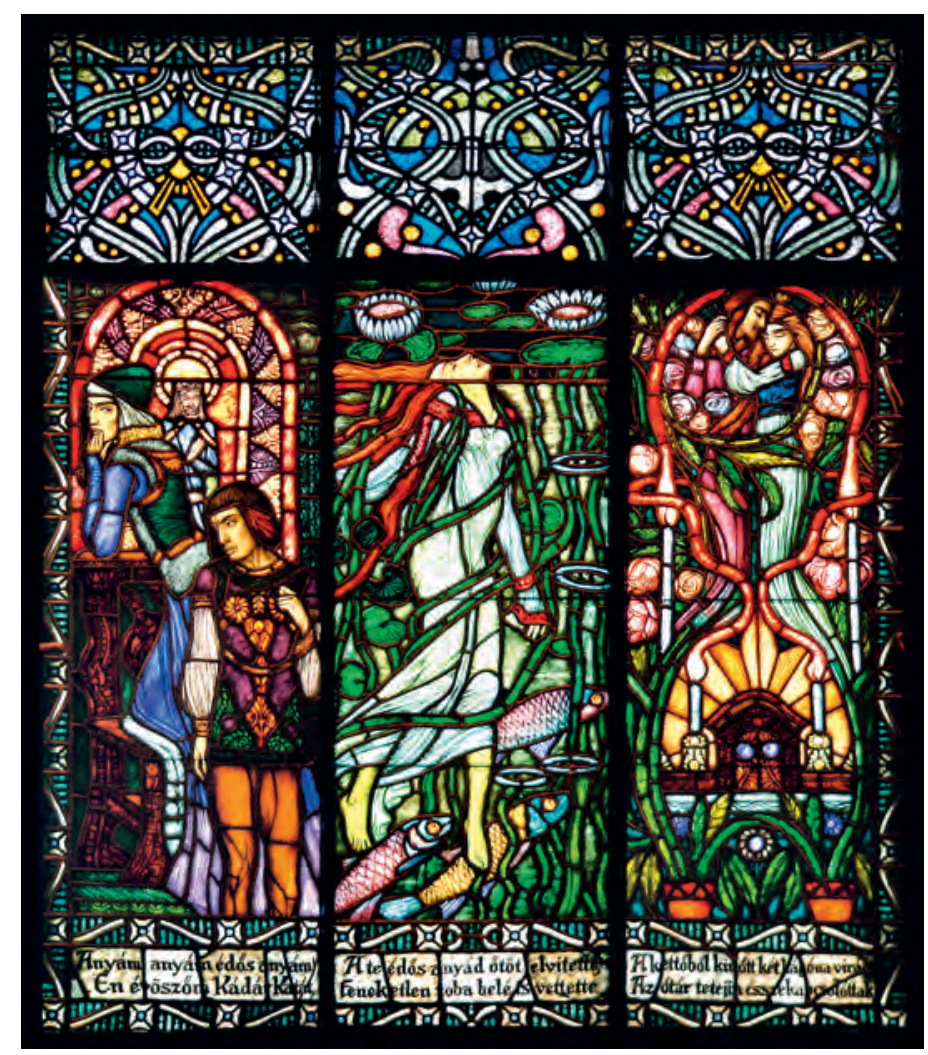

4. KÉP: Kádár Kata balladája a Kultúrpalota Tükörtermének egyik Róth Miksaüvegablakán (tervezte Nagy Sándor)

a nagyszerú építészeti és mưvészeti kvalitásai mellett az építtető Bernády nagyságára utal, hogy nemcsak rendezvénytermet építenek, hanem egy új, abban a korban Erdélyben egyedülálló kulturális központot. Az épület a kezdetektől új intézményeknek is helyet adott, létrejött a városi könyvtár (ma megyei könyvtár), zeneiskola (ma múvészeti iskola), illetve a városi képtár, amely a múzeum múvészeti részlegének az alapját képezi. Később jön létre a Marosvásárhelyi Állami Filharmónia, amely az ország egyik legnevesebb intézménye a maga területén.

Tekintve a palota gazdag külső és belső díszítését, a többféle iparmúvészeti díszítőelemet, amelyet az épületen láthatunk, illetve a kiterjedt felületeket, komoly figyelmet igényel az épület karbantartása és restaurálása. Az I960-as évek főjavítása után 2007-ben indult egy újabb helyreállítási program. Ennek kapcsán felújításra került a palota nagyterme, a kisterem, valamennyi üvegablak, és 20I3-ban befejeződött az előcsarnok 


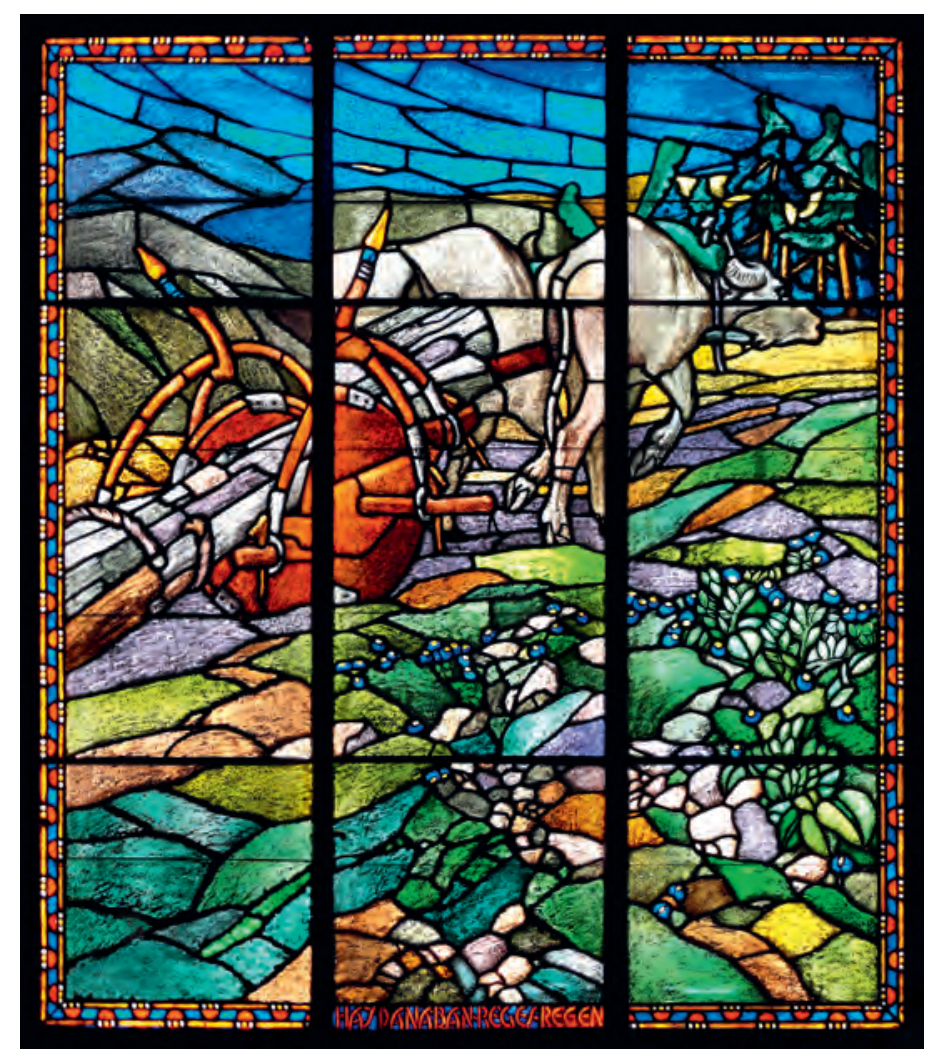

5. KÉP: A Tükörterem Toroczkai Wigand Ede által tervezett erdélyi ihletésú üvegablaka

és a lépcsőházak felújítása. Előkészület alatt áll a külső homlokzatok és a tetőszerkezet felújítása, illetve a tükörterem falfestésének a restaurálása. Párhuzamosan felújítottuk és kibővítettük a kiállítófelületeket, és bővült a kulturális kínálat. A szecesszió és Marosvásárhely összefonódását mutatja be a tükörterem mellett látható Bernády György-emlékszoba és a szecessziós-Marosvásárhely-kiállitás. Itt mutattuk be a városháza restaurált üvegablakainak középső elemeit, amelyek magyar történelmi személyiségeket ábrázolnak. Az oldalsó ablakokban Bethlen Gábor, II. Rákóczi Ferenc, Kossuth Lajos, Deák Ferenc képeit láthatjuk, míg a központi ablakban Ferenc József volt elhelyezve, fölötte az országcímerrel. Az épület 20IO-es helyreállítása során a prefektúra ellenezte, hogy az ablakok visszakerüljenek eredeti helyükre, a tanácsterembe (6. kép).

A palotában található az eredeti koncepciónak megfelelően a múzeum szépmúvészeti részlege. A múvészeti osztály jelenleg 4 kutatót és két állo- 


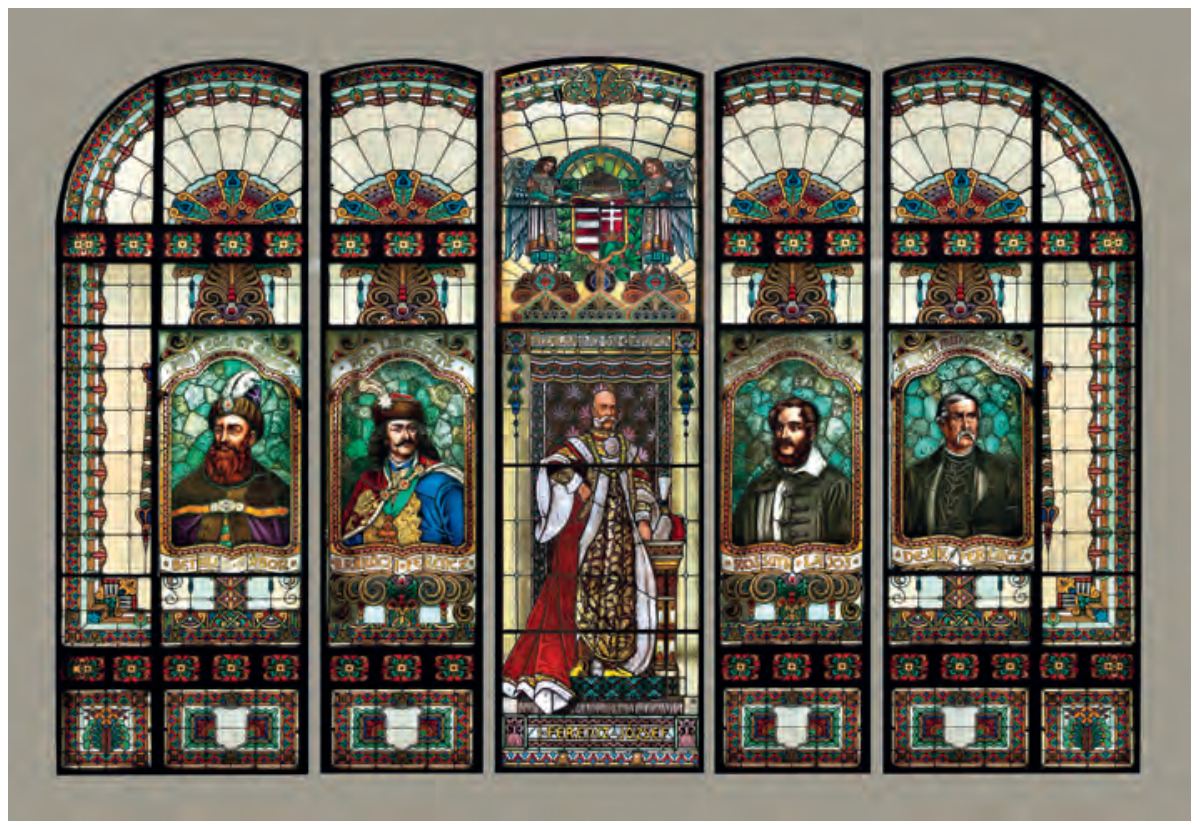

6. KÉP: Az egykori városháza történelmi személyeket ábrázoló üvegablakai (I9I8-ban eltávolították eredeti helyükről)
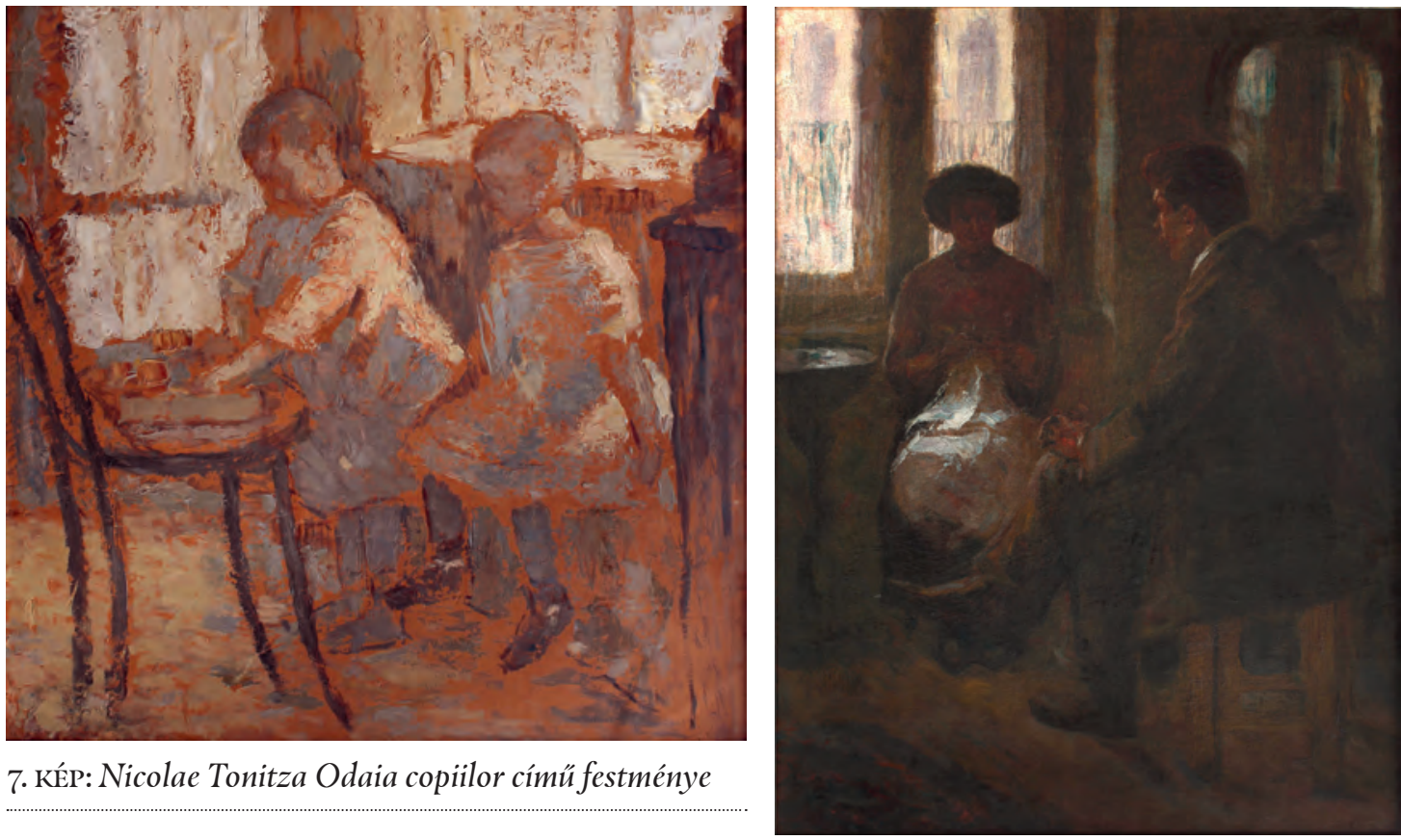

7. KÉP: Nicolae Tonitza Odaia copiilor címü festménye

8. KÉP: Hollósy Simon Ablaknál címú festménye 
mányfelelőst-restaurátort foglalkoztat. A gyúijtemény körülbelül 26oo festményt, szobrot és kerámiatárgyat számlál. A legjelentősebb állományok az ún. Bernády-gyújitemény, amely 19-20. századi festményeket tartalmaz (Munkácsy Mihály, Paál László, Lotz Károly, Vaszary János, Ferenczy Károly, Fényes Adolf stb.), és a klasszikus román múvészet, amely szintén kimagasló múvészek alkotásait tartalmazza (Theodor Aman, Ion Andreescu, Nicolae Grigorescu, Ştefan Luchian, Nicolae Tonitza stb.). A Kultúrpalotában található múvészeti gyújtemény több értékes festménnyel gazdagodott az elmúlt két évben. Ezek közül kiemelnénk a Nicolae Tonitza Odaia copiilor címú festményét (7. kép), illetve a nagybányai festőiskolához tartozó Hollósi Simon Ablaknál címú festményét (8. kép).

200o-ben nyílt újra az egykori Bernády-gyújitemény az eredeti helyszínen, a palota bal szárnyában. 2008-ban sikerült megnyitni a klasszikus és avantgárd román festészetet bemutató galériát, illetve egy külön teremben Gheorghe és Elisabeta David I50 kortárs festményt tartalmazó adományát. A 20ı6-os évben két újabb galériát sikerült megnyitni, amely Ion Vlasiu és Dósa Géza Maros megyei múvészek munkásságának állít emléket. A régészeti kiállítás elköltöztetése révén egy körülbelül 250 négyzetméter alapterületú, ideiglenes kiállításokat fogadó, korszerü kiállítóteret sikerült

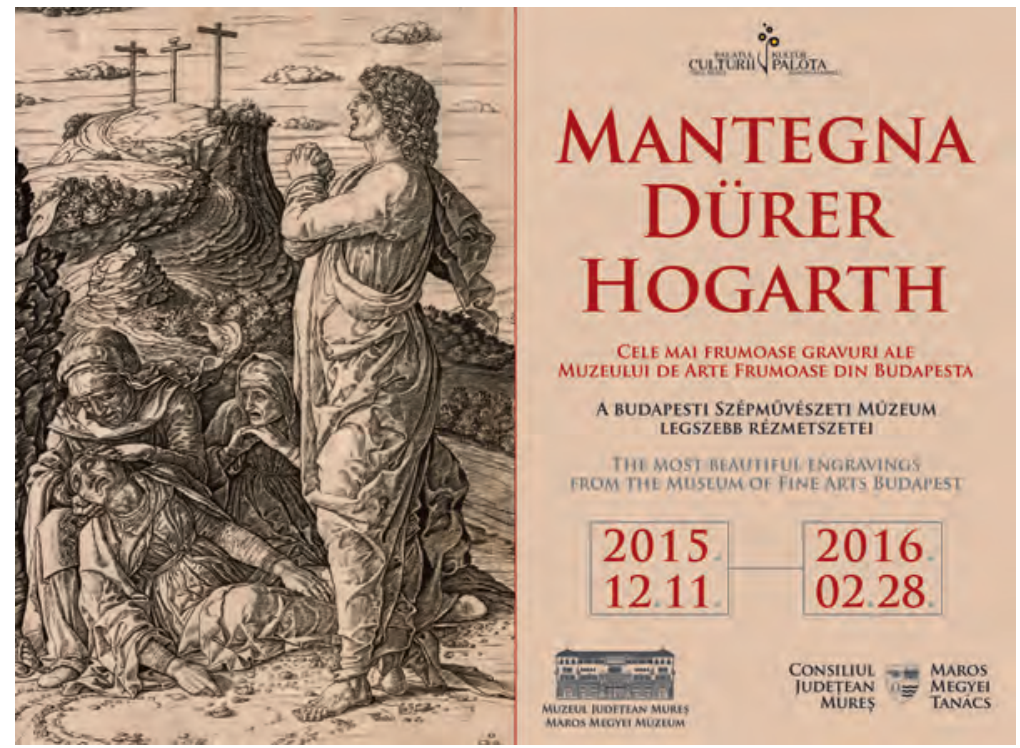

9. KÉP: A budapesti Szépmüvészeti Múzeum metszetgyüjteményéból készült kiállitás marosvásárhelyi plakátja 
kialakítani a Kultúrpalota második emeletén, amelyet egy, a Szépmúvészeti Múzeum gyújteményéből származó, Mantegna, Dürer, Hogarth - a Budapesti Szépmúvészeti Múzeum legszebb rézmetszetei c. kiállitás bemutatásával avattunk fel (9. kép). Az új kiállítótérben mutattuk be a Róth Miksa munkásságának emléket állító kiállítást, illetve 2017 tavaszán nyílik a budapesti Szépmúvészeti Múzeum Zichy-gyújteményét bemutató festészeti kiállítás.

\section{TERMÉSZETRAJZI MÚZEUM}

\section{(AZ EGYKORI SZÉKELY IPARMÚVÉSZETI MÚZEUM)}

Időrendi sorrendben az egykori Székely Iparmúzeum épülete az első, amely a múzeum használatába került. Először i889-ben merült fel az elképzelés, hogy Marosvásárhelyen létrehozzanak egy iparmúzeumot. A múzeumot építeni szándékozó Székely Gazdasági és Kulturális Egylet nyilvános gyúitést szervezett az építési költségek előteremtésére, majd a városban járó Baross Gábor miniszter hathatós anyagi támogatásának köszönhetően I89I-ben nekifogtak az építkezésnek. Az épületet Kiss István építész tervezte, a munkálatokat I893-ban fejezték be. Az épület a neoreneszánsz és a görög épületarányok ötvözése révén jött létre.

Az új intézmény célja a székelyföldi iparos hagyományok feltérképezése, dokumentálása, megőrzése, de komoly hangsúlyt kapott a külföldröl behozott mintadarabok ismertetése is. Számos makett és mintadarab maradt fenn, sok száz kerámiatárgy az Osztrák-Magyar Monarchia különböző kézmúvesközpontjaiból, de fóképpen a magyarországi és erdélyi központokból. Az Iparmúzeum I9I8 után felszámolódott, az értékes gyúijtemény egy része Kolozsvárra került, nagyjából az állomány fele maradt Marosvásárhelyen, ez jelenleg a megyei múzeum tulajdona. Kevés átalakítással fennmaradt az egykori Iparmúzeum eklektikus épülete (IO-II. kép), amely számos eredeti részletet megőrzött, így a lépcsőház festett üvegablakait is. Az üvegablakokat kívülről nem védte semmilyen külső ablak, ezért több helyen megrongálódtak, és az épület hőszigetelő képessége is jelentősen csökkent. 2008 tavaszán külső, hőszigetelő védőüveggel láttuk el a lépcsőházat, az üvegablakokat pedig Kecskeméten újították fel, így visszanyerve eredeti pompájukat. Az épület teljes rekonstrukcióját a folyamatban levő európai uniós pályázat keretén belül valósítjuk meg, és remélhetőleg 20I8-ban elkezdődhetnek a munkálatok.

Az épületben jelenleg a Természetrajzi Múzeum múködik, amely összesen hét kutatót foglalkoztat. Az épület felújitás után is a természetrajzi részleg otthona marad, illetve az épület mögött fekvő területen egy dendrológiai park készülne, amely a megye növényzetét fogja ismertetni. 


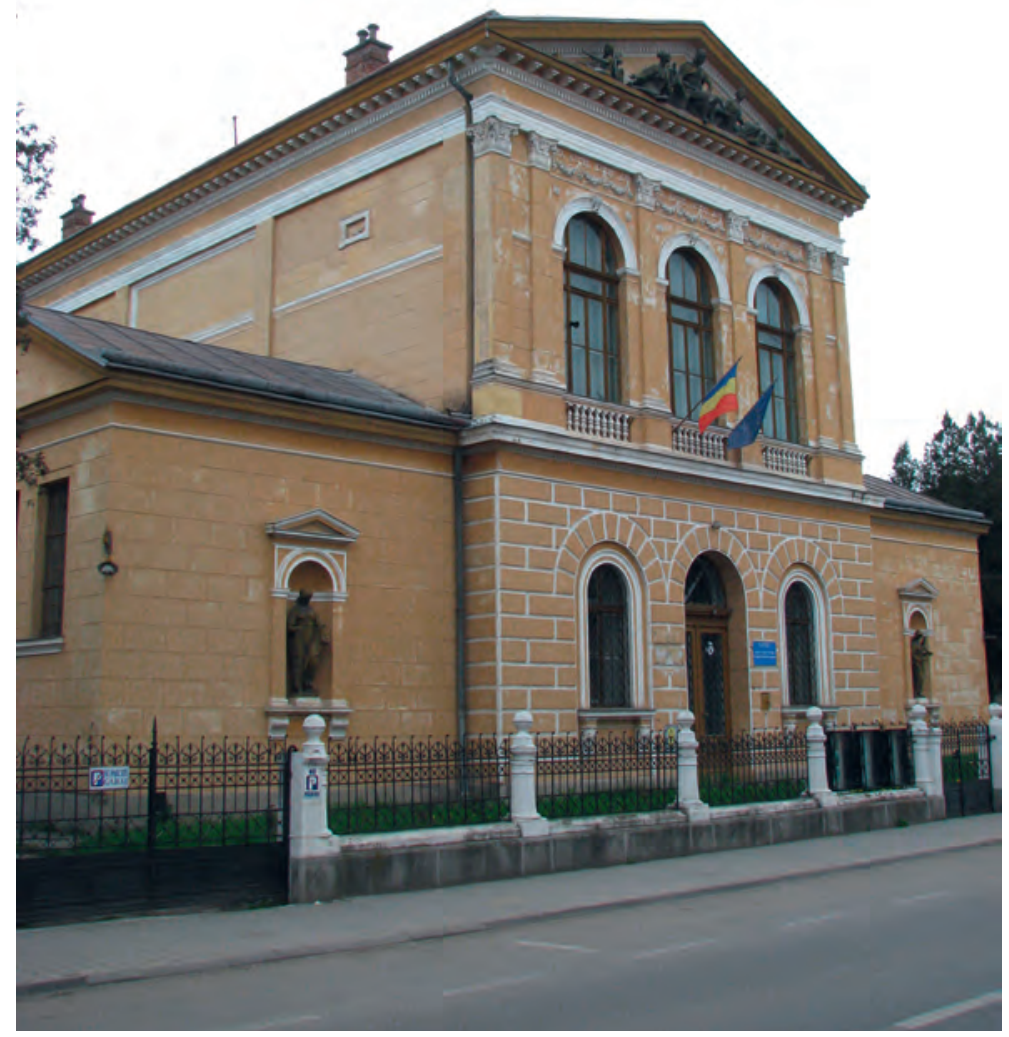

IO. KéP: Az egykori Székelyföldi Iparmúzeum, ma Természettudományi Múzeum I893-ban átadott épülete

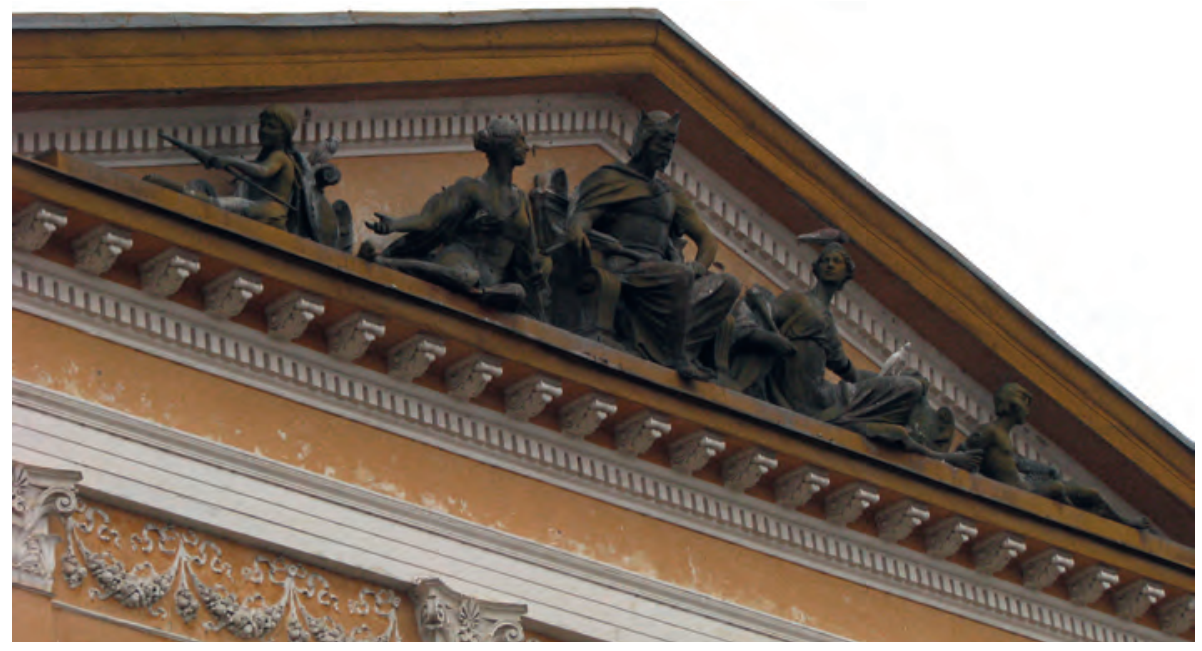

II. KÉP: Az Attila-szoborcsoport az egykori Székelyföldi Iparmúzeum homlokzatán 
TOLDALAGI-PALOTA (1752-1779).

NÉPRAJZI GYÚJTEMÉNY

A Toldalagi-palota a város egyik legjelentősebb XVIII. századi múemléke (I2. kép). A Királyi Tábla beköltözését követően Marosvásárhelyen emelkedő foúri paloták első és egyben legígényesebb példája. Építtetője gróf Toldalagi László (mh. I779), a Királyi Tábla ülnöke. Építési munkálatai I759ben kezdődtek, és több szakaszban I772-ig zajlottak - ekkor került sor a hátsó szárny teljes befejezésére.

A palota tervezó mestere Luidor János, vicepallérként pedig ennél az építkezésnél túnik fel először Marosvásárhelyen a később nagy jelentőségre szert tevő Schmidt Pál. A szobrok, faragott kőelemek elkészítése a korabeli Erdély legfontosabb szobrászára, Schuchbauer Antalra hárult, de szamosújvári kőfaragók is megfordultak az építőtelepen. A stukkódíszek készítésével kapcsolatban Romanus Lehr személyével találkozunk. A Toldalagi család számadáskönyvei a szebeni Johannes Schmidt, valamint a régeni Enyedi Márton lakatosok nevét is őrzik, az asztalosmunkát Takács Lénárd, Hujbert András, Venczel és Semberi nevú mesterek, a kályhákat a nagysajói Céra János és a szászrégeni Jámbor Sámuel rakta, az üvegesek (Sendelyes István és Locz János) segesváriak voltak. ${ }^{3}$

A palotában a negyvenes évek első felében az Erdélyi Bank Rt. múködött, az általuk tervezett nagyszabású átalakítási munkálatokat szerencsére meghiúsította a háború. Az 1960-I96I-ben zajló helyreállítási munkálatok során kerültek az épületbe a ma is ott látható historizáló kályhák - egyrészt a kerelőszentpáli Haller-kastélyból, másrészt pedig a marosvásárhelyi Bernády tér 6. és a Jókai Mór utca 26. szám alól. Jelenleg a Maros Megyei Múzeum néprajzi részlege múködik az épületben.

Az épület a Rózsák tere (a hajdani Poklos utca) nyugati során, a ferencesek templomából és kolostorából mára megmaradt torony déli oldalán található. Déli szomszédja a Bányai-palota magas neobarokk épülete, északról a ferences kolostor helyén nyitott Színház tér határolja. Zárt belső udvarú, négyzet alaprajzú épület, egy főhomlokzati és egy hátsó bejárattal. Az északi szárny hátsó, nyugati részébe foglalt félemeletes épületrész egy korábbi ház maradványa. Cseréphéjazatú manzárdtető fedi, a gerincen csillaggal díszített pléhgombokkal.

Az épület egyik múvészettörténetileg leginkább értékelhetó részlete a gazdagon díszített, hattengelyes főhomlokzat. Középen két tengely széles-

3 Orbán János: Toldalagi-Palota, Marosvásárhely, http://lexikon.adatbank.ro/muemlek.php?id=178 tortenet

I94 SOÓS ZOLTÁN 


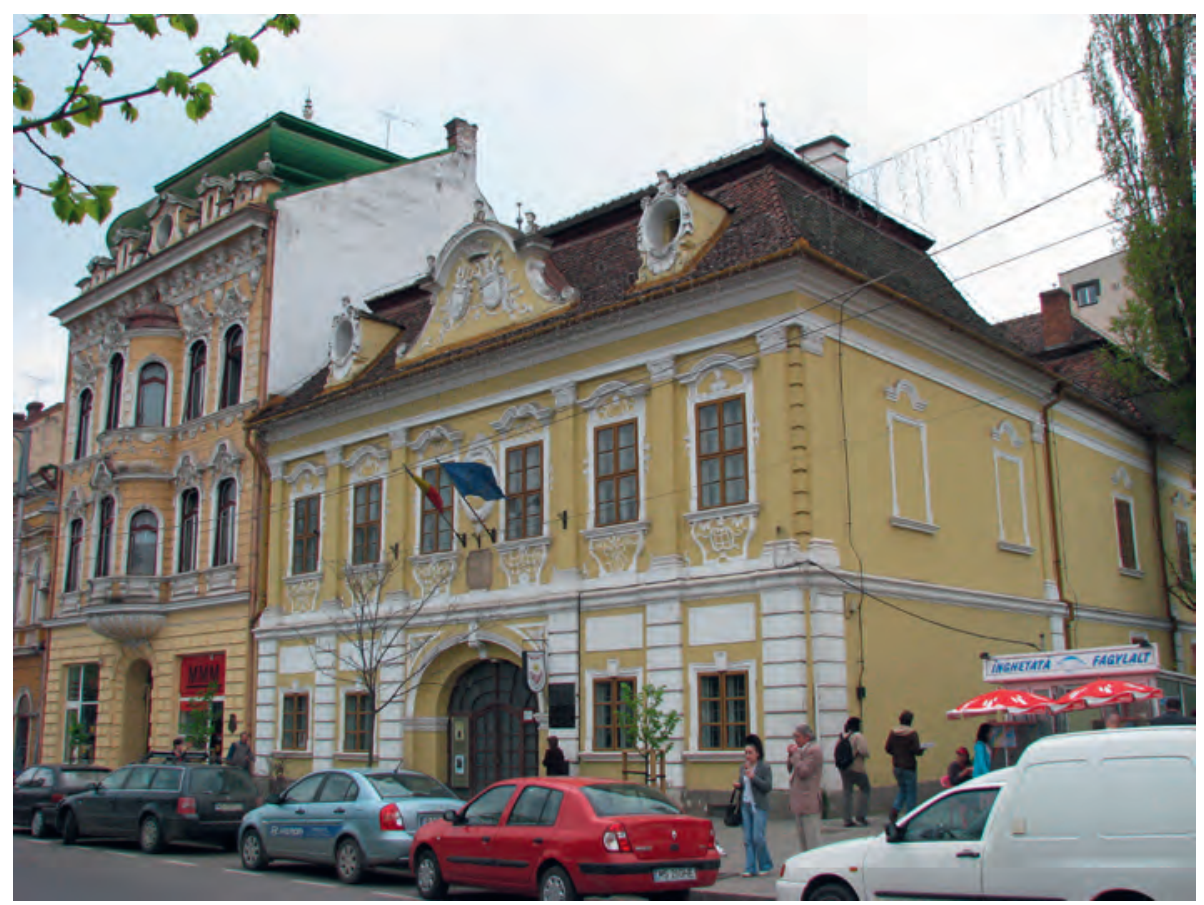

I2. KÉP: Az I772-ben befejezett Toldalagi-palota, ma a néprajzi múzeum épülete

ségben hornyos bélletû́, vállköves-záróköves díszítésú, kosáríves záradékú kapuzat nyílik, szemöldökmezejében kétoldalt háromszög alakú keretbe mintázott levéldíszekkel. A földszint tengelyeit rusztikus lizénák határolják - ezek kivételével a földszint tagolásának minden eleme (ablaknyílások, vakolt záróköves füleskeretek, tábladíszek az ablakok felett) múemléki helyreállítás eredménye -, a 20. század első felében itt még magas kirakatok és cégtáblák töltötték ki a lizénák közötti mezőket. Az emeletet a földszinttôl a homlokzati tagolóelemek vonalában golyvázódó övpárkány választja el (tagozatai a század első feléből származó fotókon egyszerúbbeknek túnnek).

Az egykori foúri városi palotát többször átépítették, eredeti berendezéséből néhány kályha maradt fenn. Az 1980-as évek elején újították fel utoljára, sajnos több esetben is szakszerútlen beavatkozások történtek, pl. a pince egykori téglaboltozatait újraöntötték betonból, a szobákban eltávolították a régi vakolatokat és helyettük cementvakolatot hordtak fel stb. Nem maradtak fenn az üvegcsillárok, és az eredeti ajtó- és ablakvasalások, zárak közül is viszonylag kevés maradt épen.

Az épület 1968-ban került a Maros Megyei Múzeum kezelésébe, és a néprajzi gyúijteménynek ad otthont. A néprajzi és népmúvészeti osztály 
gyújteménye számos értékes népmúvészeti tárgyat tartalmaz, több régió népviseletét, lakástextíliákat, kegytárgyakat, szentkép- és ikongyúijteményt, az erdélyi kerámiakészítés számos emlékét a I8-20 századból, valamint napjaink népmúvészeti alkotásait: gyékény-, kukoricaháncs-fonatok, taplóból készült tárgyak, naiv festészet. Mindegyik gyújtemény több részre van osztva a tárgyak típusa, anyaga, illetve funkciói szerint. Az első néprajzi és népmúvészeti tárgyak Aurel Filimon gyúijteményeiből származnak a 20. század elejéről, melyeknek gazdagítása további gyújtőprogramokon keresztül folytatódott, míg sikerült Maros megye valamennyi tájegységét lefedni (Mezöség, Küküllő mente, Görgény völgye, Felső-Maros völgye, Nyárád mente). Ezeknek ritkasága, tipológiai változatossága, valamint a múvészi értéke is figyelemre méltó. A kerámiagyújtemény több száz, az egykori Székely Iparmúzeum anyagához tartozó tárgyat tartalmaz, és intézményünk egyik leggazdagabb, folyamatosan gyarapodó állománya. Az utóbbi évek gyúijtómunkája során több szászföldi fazekasközpont termékét sikerült megvásárolni, elsősorban homoróddaróci és szászkézdi kerámiákat, de néhány tordai, illetve székelyföldi tárgyat is sikerült megvásárolni.

Az elmúlt évtizedek folyamatos vásárlásai következtében sajnos kevés I7-I8. századi kerámiatárgy maradt itthon, ezért intézményünk elsősorban németországi és magyar aukciósházakból vásárol újabb mútárgyakat. 20I6ban sikerült néhány itthon már ritkaságnak számító besztercei, márpodi, szebeni kerámiát vásárolni, és szándékunkban áll további erdélyi fazekasközpontok termékeit beszerezni, mint például a kürpödi vagy a nagyon ritka alvinci habán kerámiát. A néprajzi osztály gyúiteménye több mint 8000 tételt tartalmaz. Intézményünk célja középtávon egy falumúzem vagy tájház együttes kialakítása Marosvásárhely 20 kilométeres körzetében, lehetőleg a népi építészeti emlékekben gazdag Nyárád mentén.

\section{VÁRMÚZEUM. TÖRTÉNELMI ÉS RÉGÉSZETI GYÚJTEMÉNY}

A negyedik múemléképület, amely a múzeum kezelésében található, a marosvásárhelyi várban levő egykori katonai parancsnoksági épület, amely 2007. január I-ig sorozóközpontként múködött. A katonaság által használt épületet kormányhatározat alapján 200I-ben átadták a Maros megyei tanácsnak, majd a megyei tanács 2007-ben Lokodi Edit Emőke akkori tanácselnök hathatós támogatásának köszönhetően átadta az épületet a múzeumnak. A múzeum 2007 áprilisában vette át az épületet a megyei tanácstól.

Az épület egy látszólag érdektelen, jelen formájában a I9. század végén épített katonai parancsnokság, amely először a vár 1750 -es katonai fel- 


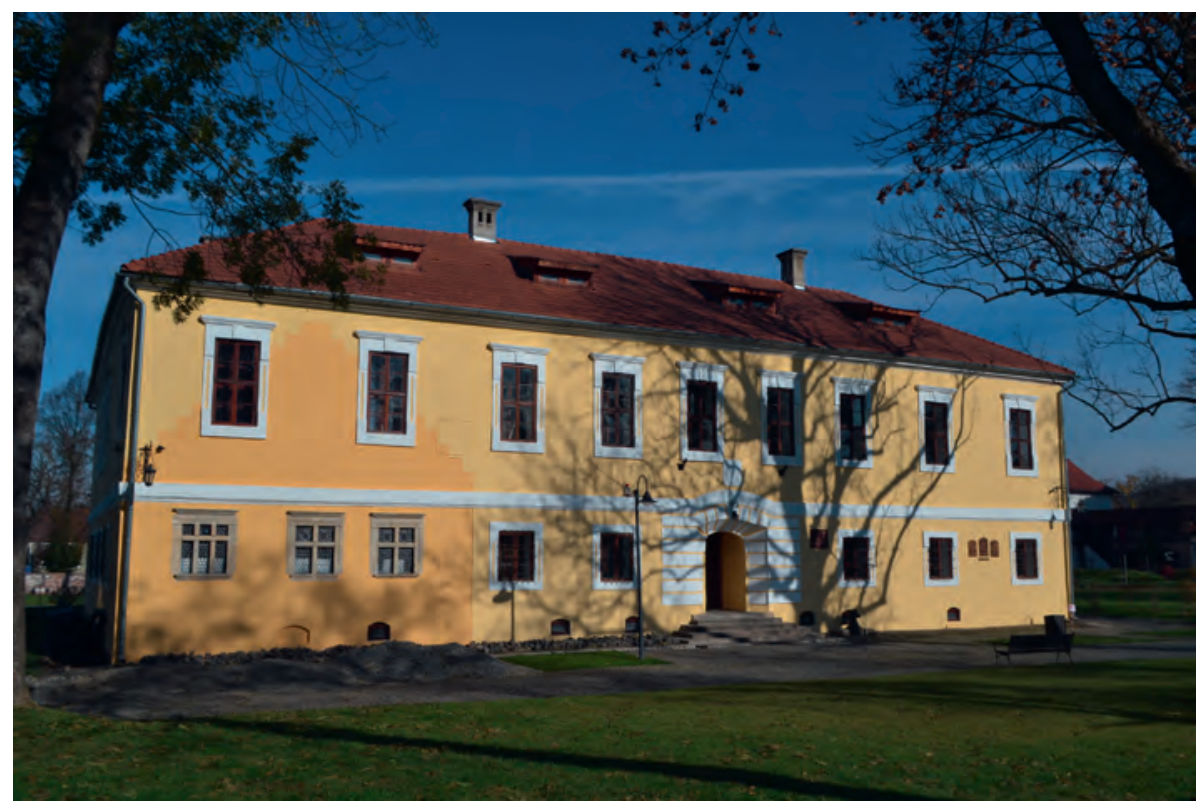

I3. KÉP: A I7-I9. században épült egykori várparancsnokság, ma a Történeti-Régészeti Múzeum épülete

mérésén szerepel (Iz. kép). A várban álló épületek jelentős része a I8-I9. század során épült az itt állomásozó osztrák, majd osztrák-magyar katonaság részére.

A várban fellelhetó múemlékek közül a református templom épülete a legjelentősebb, amely egykor Ferenc-rendi kolostor volt, és Székelyföld legjelentősebb késő gótikus múemléke. A I4. század végén épített kolostortemplom I442-ben egészült ki a ma is álló, 55 méter magas, késó gótikus toronnyal. A vár magját képező egykori kolostort az I480-as években erődítik Báthory István erdélyi vajda támogatásával. A reformáció után a kolostor épületeit elbontják, és az épülő városfalakhoz használják a romokat. Fennmaradt a templom, az egykori sekrestye, a torony és az egykori kápolna szentélye. A kolostor területét több mint tíz éve kutatjuk és ennek tudatában kijelenthető, hogy Erdély egyik legfontosabb koldulórendi létesítménye volt, amely egyaránt végzett oktatási és missziós tevékenységet, és feltehetőleg fontos zarándokhely volt a késő középkor folyamán. A reformációt követően Erdély egyik legkorábbi protestáns iskoláját alapítják meg az egykori kolostor falai közt, amely mai napig múk ödik.

A vár második fontos építészeti örökségét a várfalak képezik, amelyek a I7. századi „kolcsos várost” övezték. Ez az építmény is egyedi, figyelem- 
be véve, hogy az egykori magyar királyság egyik legkésőbb kialakult királyi városáról van szó. A városfalak az újkori Erdély katonai építészetének sajátos emlékei. Sajnos a II. Rákóczi Ferenc vezette szabadságharc után a polgári lakosságnak el kell hagynia a vár területét, a polgárházakat elbontották és a ma álló épületeket emelték helyükbe.

Az egykori várparancsnokság épületében múködő Régészeti és Történeti Múzeum 2008 óta használja az épületet. Intézményünk két meghatározó szakosztálya, a régészet és a történelem osztály használja az épület kiállító-, valamint raktárhelységeit. A régészeti és történelmi múzeum felújítási munkálatai közel nyolc évig tartottak, egyrészt az anyagi erőforrások szúkössége miatt, másrészt az épület átfogó megerősítése, aláfalazása, a építési korszakok feltárása, hiteles megjelenítése jelentett többletfeladatot a szakemberek számára. A I8. századi osztrák katonai térképek több polgárházat tüntetnek fel a katonai parancsnokságnak kialakított épület helyén. A felújítás során igyekeztünk minél több részletet feltárni a korábbi épüle-

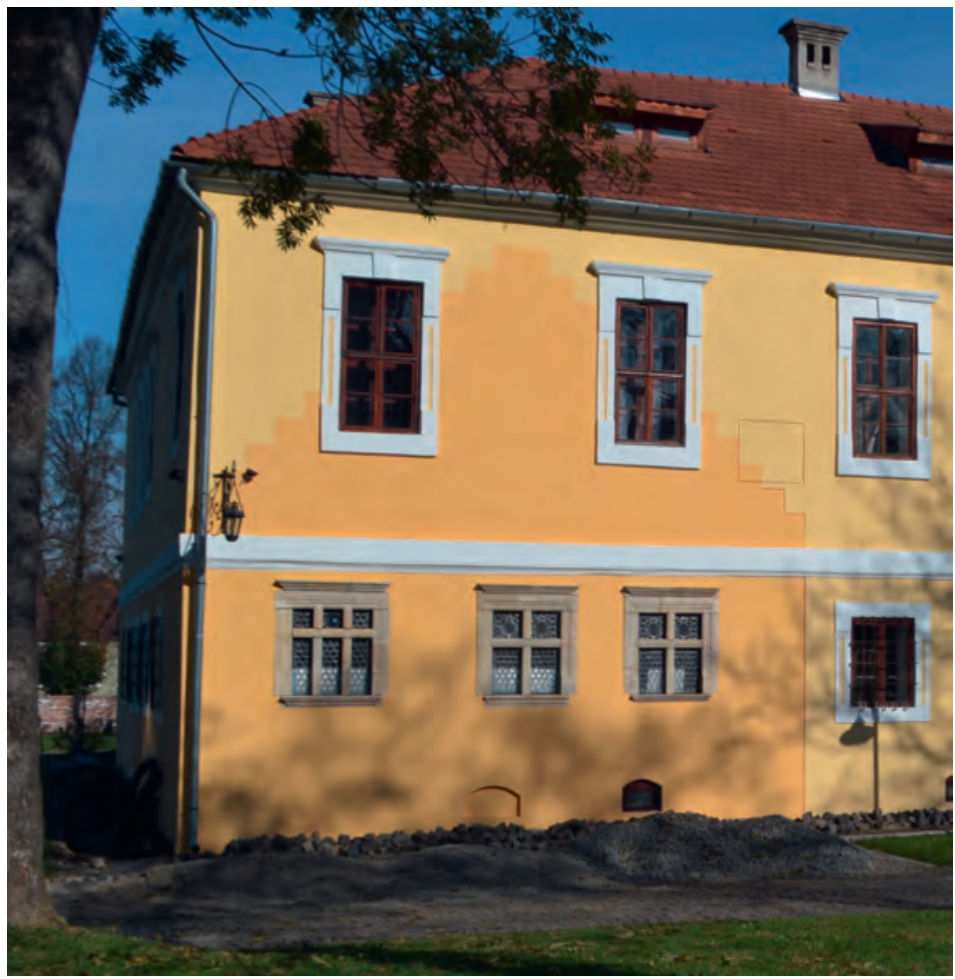

I4. KÉP: A I7. századi marosvásárhelyi elsô polgármesteri hivatal helyreállitott homlokzata, beépítve a 19. századi épületbe 
tekből, lévén, hogy egyetlen I7. századi épület sem maradt fenn Marosvásárhelyen eredeti formájában. A feltárások során egyértelmúvé vált, hogy az épület keleti, illetve nyugati szárnya egy-egy korábbi polgárház részleteit tartalmazza. A katonai parancsnokság két polgárház felhasználásával épült, az utcafrontra merőleges, háromosztatú házakat középen a fóhomlokzatnál egy újabb szárnnyal összekötötték, létrehozván egy U alaprajzú épületet. A két korábbi különálló épület szerkezetileg jól elkülönül a pinceszinten a barokk hozzáépítéstől. A keleti szárnyat képező I7. századi épület földszinti része csak részletekben maradt fenn, nagyobbrészt átépítették.

A nyugati szárnyat képező i7. századi épület sokkal épebben megőrződött. A négyosztatú épület a földszint párkánymagasságáig fennmaradt, mindössze az ajtó- és ablakosztás módosult részlegesen. A I7. századi építmény eredetileg földszintes volt, a barokk korban épül egységesen emelet az U alakú épületre. A nyugati szárny tehát teljes mértékben megőrzött egy I7. századi épületet, felvetődött a kérdés, hogy kié lehetett az épület, illetve mennyit változott a jellege az átépítések során. Az első, utcafronton levő teremnek a keleti oldalon volt egy külön bejárata az udvar felől. A homlokzaton a két barokk ablak kutatása során előkerült egy harmadik reneszánsz ablak, illetve részlegesen a másik két reneszánsz ablak béllete. Az első és második terem közti elfalazott nyugati átjáró kibontása során számos reneszánsz ablakkeretrészlet került elő, amelyeket restaurálás és részleges kiegészítés után visszahelyeztek az utcafront ablakbélleteibe. Két kétosztatú és egy háromosztatú ablakot állítottak helyre a töredékek restaurálása után. A homlokzat helyreállítása lehetővé tette az egykori reneszánsz oromzat kutatását, amelynek alsó két elemét sikerült azonosítani. Ennek alapján nagy valószínúséggel kiszerkeszthető volt az egykori fogazott oromfal. A falkutatások során előkerültek a I7. századi ablakbélletek, amelyek közül a középső béllet épen fennmaradt, a tóle keletre levő ablakbéllet közel kétharmada, míg a nyugati ablakbéllet egyharmada maradt fenn. Az előkerült részletek alapján lehetővé vált az ablakok és az oromfal hiteles helyreállítása, amely Marosvásárhely jelenleg egyetlen helyreállított reneszánsz homlokzata (I4. kép).

A belső terek kutatása tette lehetővé az épület rendeltetésének a meghatározását. Az első nagyobb terem 42 négyzetméter alapterületú, feltehetóleg ez volt az egykori épület - városháza - gyúlésterme. A második helyiség szintén 42 négyzetméter alapterülettel rendelkezik, szabálytalan négyszög alaprajzú. A feltárások során előkerült a I8. századi átalakítások során elfalazott és feltöltött pincelejáró, valamint egy észak-dél irányú o,7 m szélességú fal, amely a pincelejárót választotta el a mellette levő helyiségtôl. A helyi- 


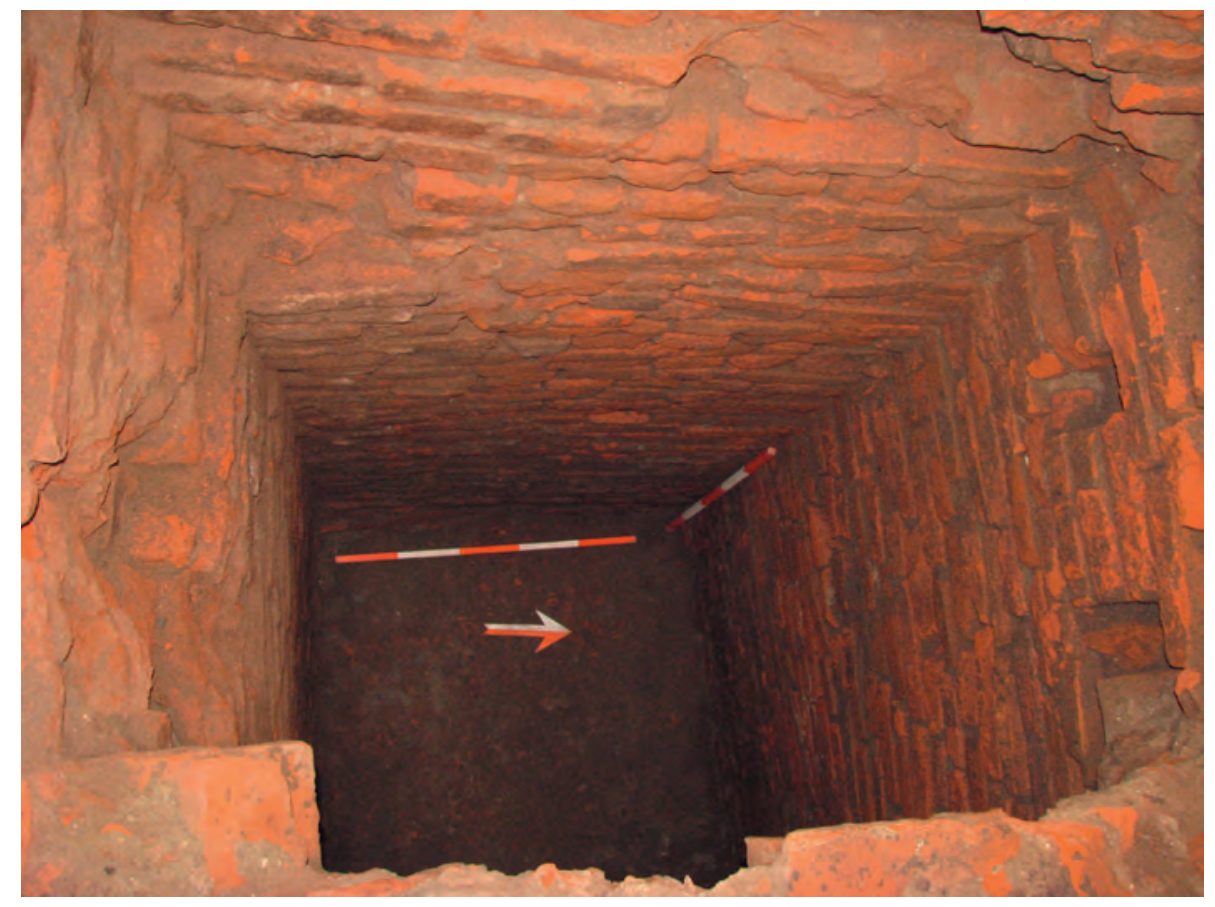

I5. KÉP: Az egykori I7. századi városi tömlöc

ség középső részén két, egymástól I,4 méterre levő pilléralapozás került elő. A pillérek a belső faltól I, 4 méterre helyezkedtek el, négyzet alakú teret zárva közre. A korabeli analógiák alapján minden kétséget kizáróan egy reneszánsz konyha maradványai kerültek elő, a falra, illetve az oszlopokra egy füstfogó kémény volt ráépítve. Az oszlopok közt kisebb túzteret képezhettek ki edényeknek, míg a túztér hátsó felében nagyobb nyílt teret alakítottak ki sütéshez. A harmadik helyiség feltárása tette lehetővé az épület eredeti rendeltetésének meghatározását. Az alapozások vizsgálata során a 40 négyzetméter nagyságú terem délnyugati sarkában egy 4,5 méter mély, I,5 $\times$ I,5 méter alapterületú, téglával falazott vermet azonosítottunk (I5. kép). A méretek alapján bizonyosan egy I7. századi tömlöcöt azonosítottunk, hiszen a korabeli polgárházak jóval kisebb tárolóvermekkel rendelkeztek. A tömlöc kialakítása az épület építésével egy időben történt. A városháza építése összefügghetett az I6ı6-os királyi városi rang megszerzésével.

A I8. század ötvenes éveiben kötötték össze a két I7. századi épületet, kialakítva a barokkos $U$ alakú szerkezetet. Ekkor épült az emeleti rész. Az épület utolsó jelentős átalakítása az I870-es évekre tehető. Az osztrák- 
magyar hadsereg 22. gyalogezrede parancsnoki épületének emeletét megmagasították, az épület belső udvarában boltozott folyosók épültek, illetve kicserélték a nyílászárók jelentős részét. Az átépítést jól dokumentálja az ajtókon, ablakokon fennmaradt I877-es pecsét. Az épület mostani felújítása során előkerült több teremben a I9. századi díszítőfestés. Három teremben azonosítottunk díszítőfestést. A három teremből, a főhomlokzatnál elhelyezkedő „tiszti szalon” festését sikerült helyreállítani, illetve előkészítettük a szalontól keletre levő terem sablondíszítésének újrafestését. A harmadik, a nyugati szárnyban elhelyezkedő terem festése töredékesen maradt fenn, itt kerül kialakításra az állandó kiállítás.

A felújított épületben az elmúlt évek során több sikeres kiállítást mutattunk be: Leonardo da Vinci zseniális találmányai, A pestis, A kávé története, Gyámolító gyógyír, kúrálópirula (gyógyszertörténeti kiállítás), Vida Árpád marosvásárhelyi festőmúvész emlékkiállitása stb. Az ideiglenes tárlatok célja, hogy a közönség megszokja az új helyszínt. Ennek érdekében számos egyéb rendezvénynek adott helyet az épület, mint például a Tavaszi zsongás húsvéti rendezvény, történelmi előadások, cégrendezvények stb. Az első állandó tárlat 2018 augusztusában fog megnyílni, és tematikájában a I7. századi székely városiasodást mutatja be, különös tekintettel Marosvásárhely fejlődésére. Az egykori Székelyvásárhely az egyetlen olyan székely település, amely i6ı6-ban megszerezte a királyi városi rangot.

A kiállítás a fentebb leírt városháza termeit foglalja majd el, az első teremben, amely a tanácsterem volt, az egykori városi törvénykönyvet, céhek életét mutatjuk be. A második teremben kerül bemutatásra egy erdélyi reneszánsz konyha, korabeli receptekkel és berendezéssel, a harmadik teremben a tömlöccel kapcsolatosan mutatjuk be a boszorkányüldözést és a pereskedések menetét.

A történeti adatok ismertetése mellett bemutatjuk a I7-I8. század tárgyi hagyatékát, amely szemlélteti a korabeli Erdély gazdagságát, fejlettségét. A mútárgyak egy része a múzeum korábbi gyújteményéből származik, nagyobbrészt azonban az elmúlt öt évben vásároltuk különböző gyújtőktől, illetve egy külföldi aukciósházból. Az újonnan beszerzett mútárgyak közül a Petrus Bartesch III. brassói ötvösmester múhelyében készült aranyozott ezüstkanna a legértékesebb. Az I680-as években készült kanna jól szemlélteti az erdélyi reneszánsz múvészet gazdagságát, fejlettségét. A kannát akantuszlevelekkel és virágmotívumokkal díszítették (I6. kép).

$\mathrm{Az}$ erdélyi ónmúvesség bemutatásához mintegy húsz értékes tárggyal gazdagítottuk a múzeum gyújteményét. Kiemelendő egy I7. századi segesvári ónkanna, egy I8. századi átalakított, hatszög alakú gyömbértartó, több 


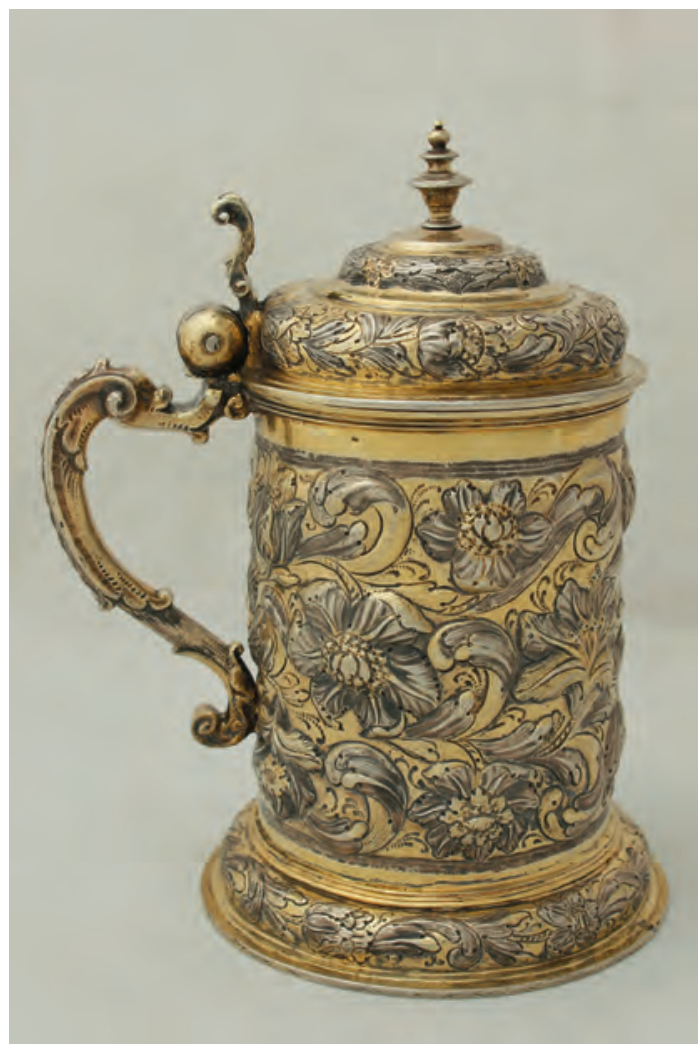

I6. KÉP: Brassói fedeles kanna Paulus Roth mühelyéből

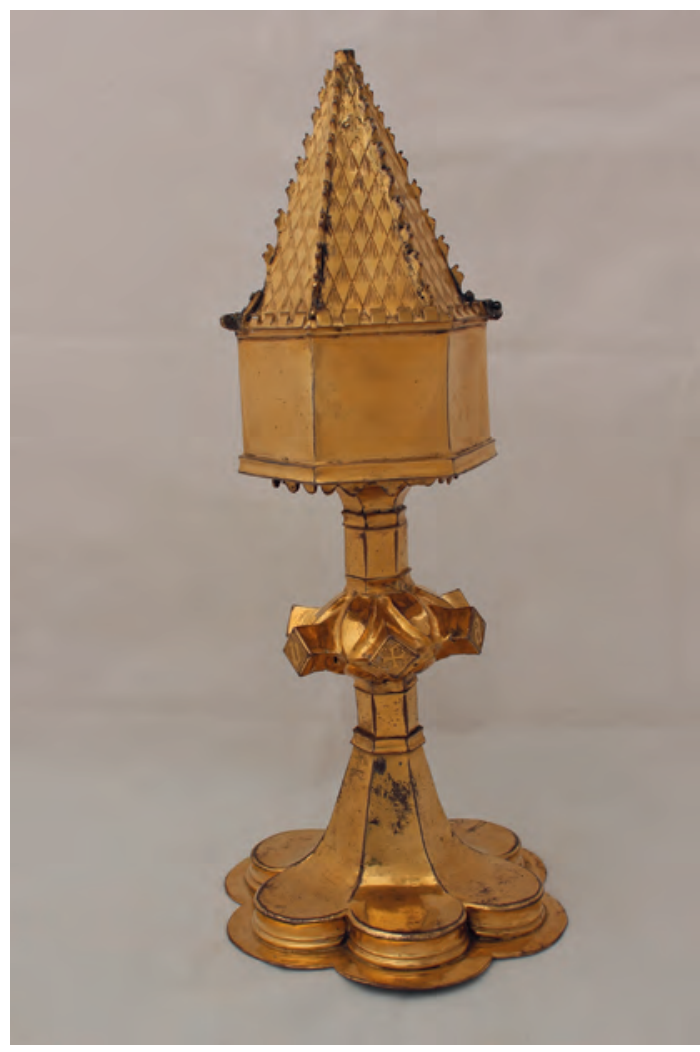

I7. KÉP: 15. századi cibórium

erdélyi, ún. delfines mozsár, illetve a felsőporumbáki üveghutából származó üvegpoharak és kannák. A kiállítás érdekessége, hogy látható lesz az egykori városháza tömlöcében megtalált egykori konyha edénykészlete. Több, mint tizenöt edényt sikerült restaurálni a maradványokból. A városháza bútorzatát korabeli ritkaságszámba menő tárgyakkal szemléltetjük. A szakirodalomból ${ }^{4}$ már ismert Teleki Sámuel sáromberki, I653-ban készült asztala, vagy az 1622-ben készült, gazdagon faragott és pompásan festett kétajtós szekrény, de különlegesnek számít a segesvári Misselbacher család hagyatékából származó reneszánsz láda is. A kiállítás célja, hogy betekintést adjon a I7. századi Erdély és Marosvásárhely gazdasági és múvelődéstörténeti életébe.

Előkészület alatt áll a májusban megnyíló, Maros megyei kincseket és

4 B. Nagy Margit: Reneszánsz és Barokk Erdélyben. Bukarest I970 Kriterion. II5 kép, I25 kép. 
múzeumi értékeket bemutató kiállítás, amelynek célja bemutatni a múzeum utóbbi hat évben vásárolt vagy régészeti ásatások alkalmával gyújiött mútárgyait.

A sok száz tárgyat felölelő kiállítás keretében valamennyi múzeumi szakosztály állománygyarapodását bemutatjuk.

A vásárolt tárgyak közül kiemeljük a Fischer-aukciósházban vásárolt, Erdélyből származó, I5. század eleji aranyozott rézből készült cibóriumot (I7. kép), illetve Trozner András 76 darabból álló fegyvergyúijteményét, amely több egyedi darabot tartalmaz. Az egyik legértékesebb mútárgy a Paul Poser prágai fegyvermúhelyéből származó I 7II-es vadászpuska, különlegességnek számít a román hadsereg tisztje által használt, 20. század eleji Mauser pisztoly vagy a második világháború egyik fontos erdélyi csatateréről, a Marosorbóról származó MG 34 géppuska. Több első világháború előtti magyar gyártmányú pisztoly került a gyúiteménybe, illetve egy második világháborús, Marosvásárhelyről származó puska, amelyre felvésték az egykori tulajdonos nevét és lakcímét.

A régészeti leletek közül kiemeljük a marosvásárhelyi várban elókerült középkori és újkori leleteket, a nagyernyei terelőút nyomvonalán feltárt gepida női sírból származó ezüstfibulákat, illetve a tófalvi határban előkerült hun kori lovas sírban talált, drágakövekkel díszített aranycsatot. A kiállítás katalógusa hasznos útmutatót fog tartalmazni a gyúitőknek és a múzeumbarátoknak egyaránt.

A Történeti és Régészeti Múzeum gyújteményei nagyobbrészt az intézmény Mărăști (egykor Vörösmarty) utcai raktárában található. A múzeum bázisaként szolgáló épületben található az intézmény adminisztrációja, a több mint húszezer kötetet tartalmazó szakkönyvtára, a restaurátormúhelyek és a kutatók irodái.

A történelem szakosztály a múzeum legrégebben megalakult részlege, amely jelenleg 7 kutatót foglalkoztat. Az állomány törzsrészét a I9. század végén, Ráth Károly által alapított Székely Iparmúvészeti Múzeum hagyatéka képezi, amely az első világháború után megszúnt múködni. Az egykori épület mindvégig a múzeum tulajdonában maradt, jelenleg a természetrajzi múzeum múk ödik benne. Az 1938-ban újraalakuló történeti múzeum a Kultúrpalotában múk ödött 2006 végéig. Ezt követően a palotában lévő raktárakat egy új, korszerú épületbe költöztettük, a történeti részleg kiállításai pedig 2009 óta a marosvásárhelyi várban, a hadseregtől 2007-ben átvett épületben kaptak helyet.

A történeti részleg állománya mintegy tízezer tárgyat számlál, amelyek a következő gyújteményekben találhatók: 


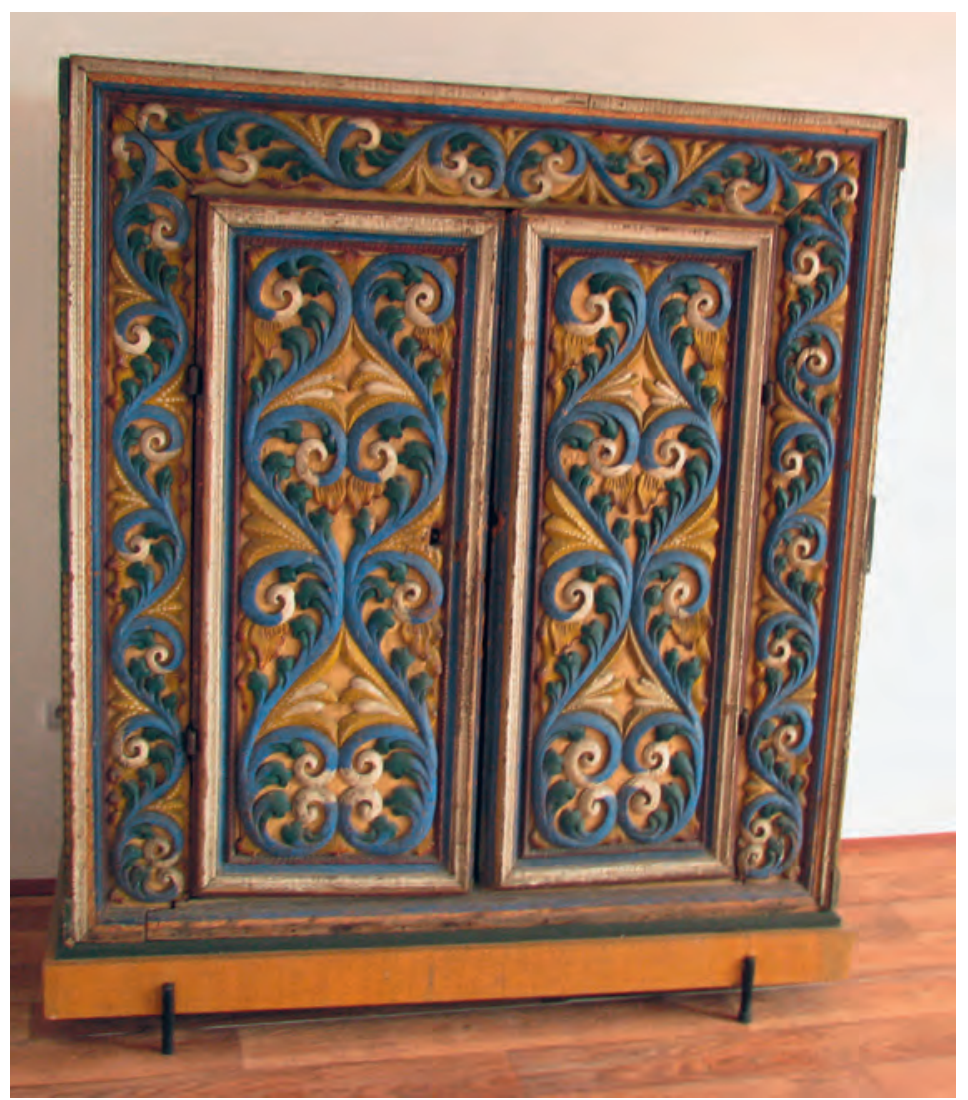

I8. KÉP: I622-ből származó erdélyi szekrény

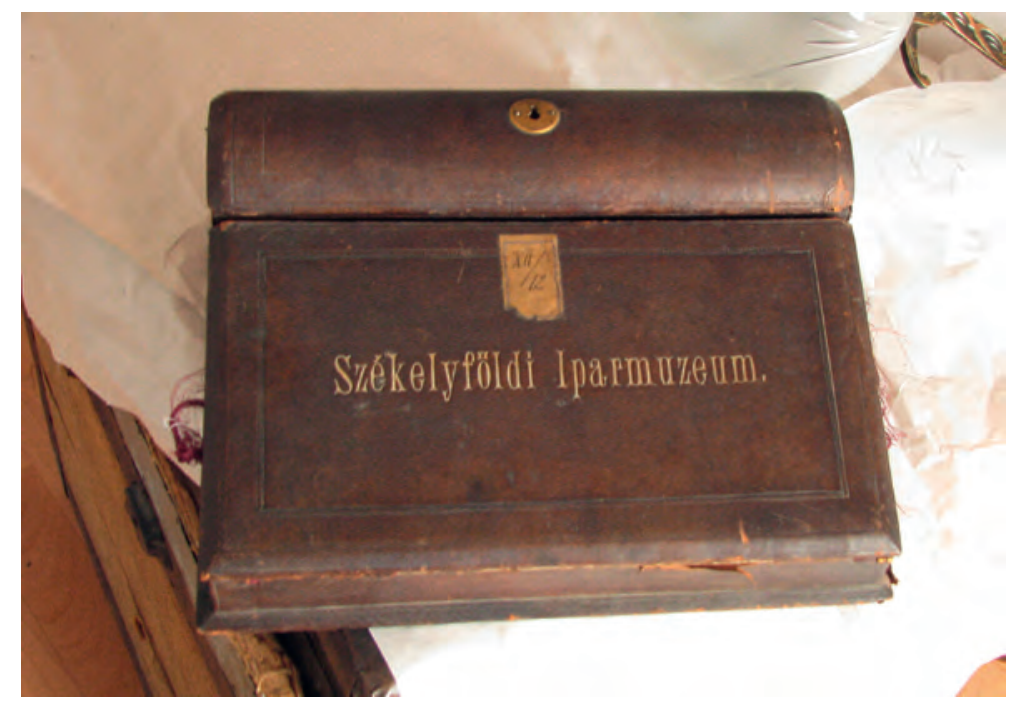

19. KÉP: Irattartó az egykori Székelyföldi Iparmúzeumból 
- Bútorgyúijtemény, amelyben néhány ritka és értékes darabot kiemelünk, így az I622-ből való szász eredetú, reneszánsz kétajtós szekrény (I8. kép), barokk falitéka, I7. századi karosszék a gernyeszegi kastélyból, bull-technikával díszített ülőgarnitúra és tükörállvány stb.

- Üveggyúitemény: különféle erdélyi, magyarországi üveggyárak termékei, néhány importdarab, említésre méltó a görgényüvegcsúri, sepsibükszádi, alsóárpási, felsőporumbáki gyúijtemény.

- Porcelángyúijtemény: jelentős, részben 19-20. századi eredetú állomány, néhány I8. századi tárgy is fellelhető.

- Technikai gyújtemény: a törzsanyagot az egykori Székely Iparmúzeum anyaga képezi (I9. kép), amely a későbbiekben jelentősen kiegészült órákkal, múszaki kellékekkel (földmérő múszerek), elektronikai cikkekkel (rádiókkal), lámpákkal, fotókellékekkel stb. A gyújtemény fontos része a marosvásárhelyi Kántor fotóstúdió 2012-ben vásárolt több mint húsz darabot számláló hagyatéka, amely több, ritkaságnak számító készüléket tartalmaz.

- Textilgyújtemény: néhány régi nemesi ruhadarabot tartalmaz, szónyegeket, céhes zászlókat, illetve 20. századi katonai egyenruhákkal egészült ki.

- Fotótár: régi fotókat, üvegnegatívokat, képeslapokat, üdvözleteket tartalmaz, több, mint hétezer fotót. A gyúitemény legfiatalabb része az I500 darabot számláló, erdélyi fürdőket ábrázoló Zepeczáner Jenőféle fotógyưijtemény.

- Levéltár: jelentős része feldolgozatlan, főleg I8., I9. és 20. századi anyagokat tartalmaz.

A régészet szakosztályon jelenleg 8 régész szakember teljesít szolgálatot, ez a legfiatalabb szakosztály, 2004-ben alakult. Létrehozását a gyorsan gyarapodó állomány tette szükségessé. Ennek oka a törvénykezés korszerúsítése, amely valamennyi új beruházás esetén kötelezi a beruházót a leletmentési munkálatok elvégzésére. A 20. századból fennmaradt régészeti anyag elsősorban a kommunizmus idején elvégzett nagyobb munkálatok helyszínéről származik, mint például a maroskeresztúri római város, a marosvécsi római castrum, a mezősámsondi bronzkori lelőhely stb. Ez az állomány jelentősen kibővült az elmúlt tíz évben, főleg a marosvásárhelyi várban végzett ásatások gazdag anyagának köszönhetően (2O-2I. kép). A marosvásárhelyi várban található Vártemplom épületegyüttese egykor Erdély legjelentősebb királyi alapítású ferences kolostora volt, amely két és fél évszázadon keresztül múködött. Ezt követően a reformáció után a várba beköltözött a vásár- 
helyi polgárság. Rendkívül gazdag középkori és újkori leletanyaggal bővült a múzeum gyújteménye, de erdélyi viszonylatban is fontos és meghatározó régészeti anyag került a felszínre. Középtávon további jelentős bővülés várható az infrastrukturális beruházások, autópálya-építések kapcsán.

A múzeum rövid ismertetéséből kiderül, hogy látványos, gazdag és változatos múzeumi gyújteménnyel rendelkezünk, sajnos az anyag egy jelentős része még mindig kutatatlan, a kiállítások eddigi hiányosságaihoz a szakemberállomány foghíjassága is hozzájárult. Az 1960-70-es években a gyưjités jelentős részét az államosítások, elkobzások során bekerült tárgyak jelentették, amelyek egy része sajnos soha nem került a múzeum raktárába, hanem a feketepiaci keresletet elégítette ki, másik részét a szakemberhiány miatt senki nem kutatta, esetenként elófordul, hogy nem is leltározták a tárgyakat. Tehát: tudatos gyúitési koncepcióról az I990-es évek közepéig nem beszélhetünk, egyrészt a szúkös anyagi források, másrészt a romániai törvénykezés nehézkessége miatt, harmadrészt pedig ismét a szakemberállomány hiánya húzódott meg a háttérben.

Az ekkor begyújtött tárgyak jelentős részéről nem áll rendelkezésünkre részletes információ. (Hiányzik a tulajdonos neve, nincs részletes szakmai leírása, elemzése, nincsen fotózva, és sok esetben nincsenek restaurálva.) $\mathrm{Az}$ ismertetett múködési problémák egy része tehát öröklött, a másik részt pedig igyekszünk minél hamarabb megoldani a belső újjászervezéssel, amely egy újraleltározást és a szakemberállomány frissítését jelenti.

Az első fontos lépés megtörtént, ugyanis a történelem részleg raktárait átköltöztettük egy felújított, korszerú épületbe, ahol a múzeum adminisztrációja, vezetősége és a restaurátormúhelyek is helyet kaptak. A megyei tanács támogatásának köszönhetően sikerült felújítani az épületet, és az egykor szétszórt, öt különböző épületben levő tevékenységet összevontuk egy új logisztikai központba. Itt állandó felügyelet alá kerültek a tárgyak, a beszerzések észszerúsödtek, kéznél van a szakkönyvtár, és a döntéshozók mindenkori elérhetősége is jelentősen növelte a hatékonyságot.Az átszervezés révén a múzeum visszaszolgáltatott két kisebb méretú, de ugyanakkor a célnak nem megfeleló épületet, amelyekben a restaurátormúhelyek és a könyvtár múködött (a könyvtár épületét visszaigényelték). Az egyéb tevékenységek átköltöztetése révén sikerült megkétszerezni a Kultúrpalotában levő képtár kiállítófelületét, amelyet addig raktár foglalt el, illetve növekedett a Néprajzi Múzeum kiállítófelülete a könyvelőség és titkárság átköltöztetésével.

A költözés során új helyett kapott a nagyrészt feldolgozatlan, ismeretlen 


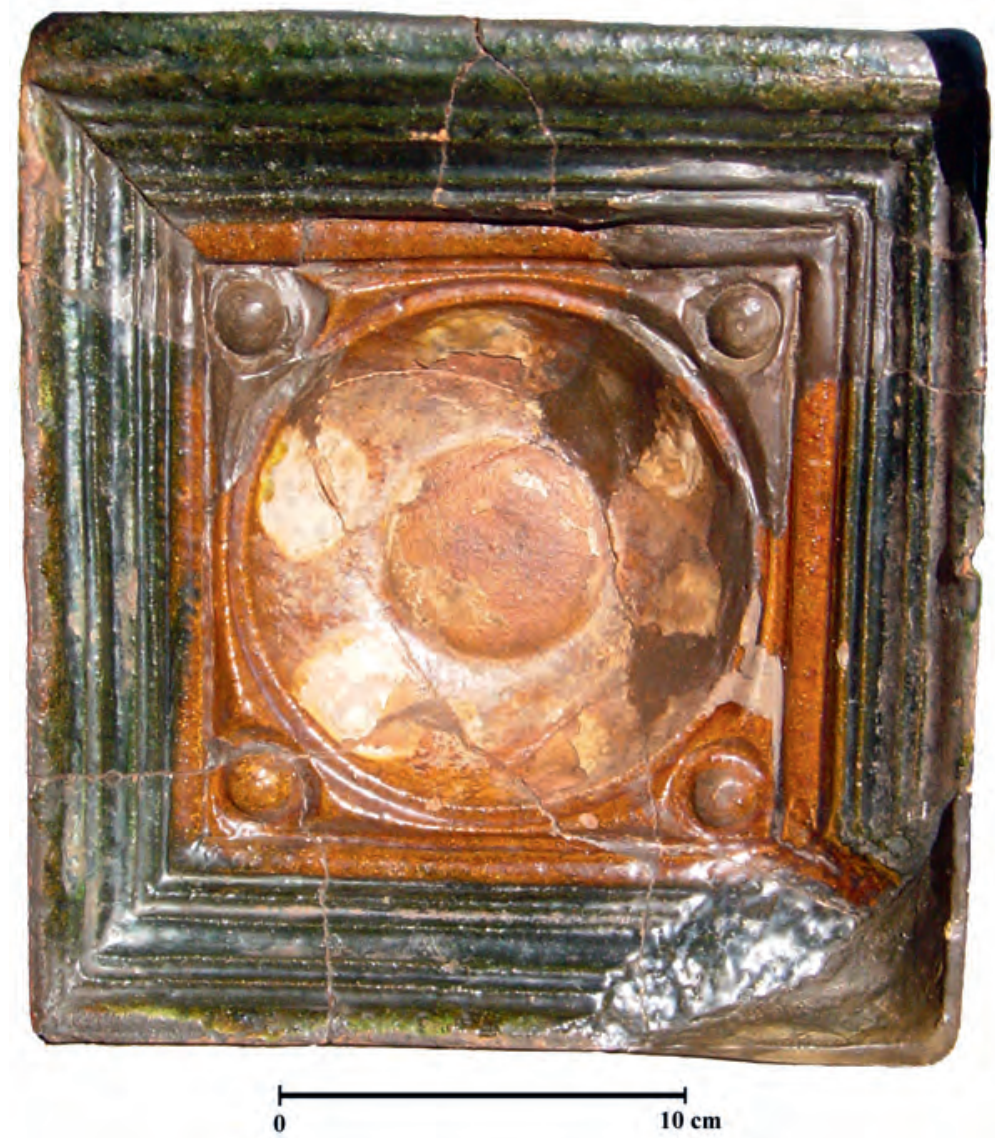

20. KÉP: Késő gótikus, I6. század eleji kályha, amely a marosvásárhelyi vártemplom régészeti kutatásakor került eló

levéltár, amelynek újjászervezése 2008 szeptemberében kezdődött. A könyvtárunk körülbelül I6 ezer kötetet számlál, 2007 tavaszán kezdtük a költöztetést és újjászervezést, amely révén a könyvállomány felének új polcrendszert sikerült biztosítani, és elkezdtük az újraleltározást. Számos szakintézménnyel felvettük a kapcsolatot a cserekiadványok felfrissítése érdekében. A könyvtár újjászervezése befejeződött, és két kiadvány is készült a gyúijteményünkben levő régi könyvekről. A Maros Megyei Múzeum örökségvédelemben betöltött szerepe fokozatosan növekszik, részben a szaktanácsadás, a múemlék-felújítások kapcsán, részben a múzeum által birtokolt, használt épületek felújítása kapcsán.

Az ügyintézés korszerúsítése illetve az épületek felúiítása mellett legalább olyan fontos volt a leltárak ellenőrzése, digitalizálása, illetve a kutatási 


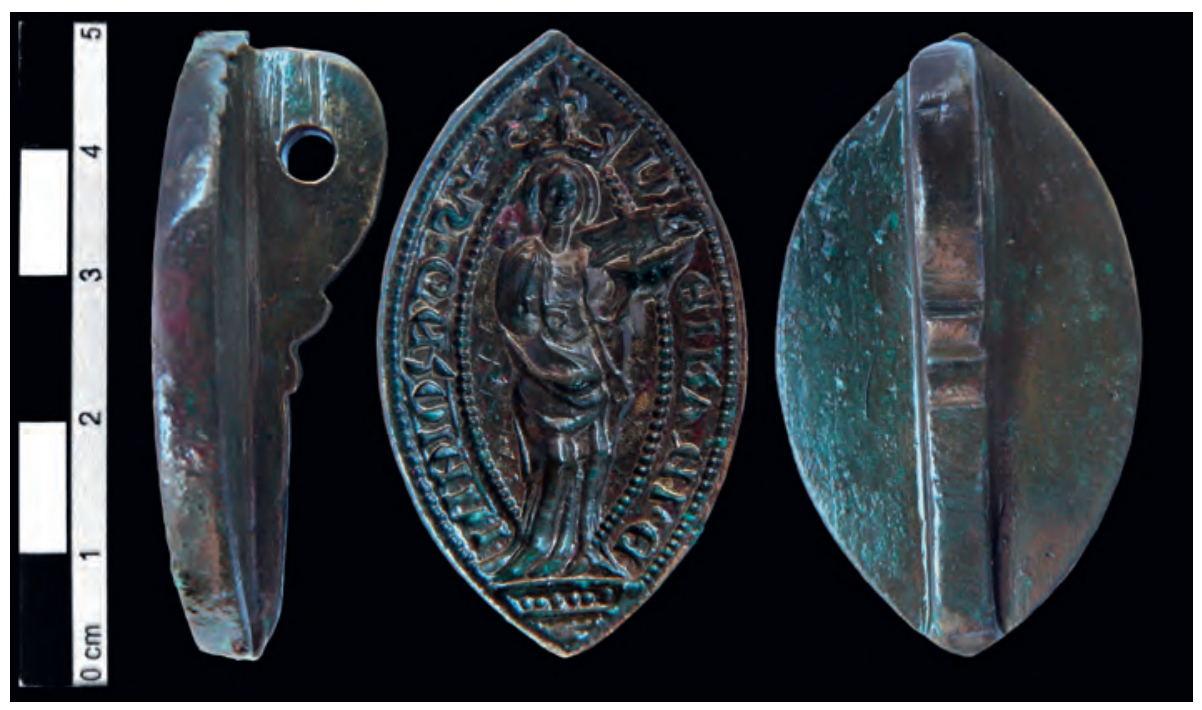

2I. KÉP: Az egykori győri ferences rendházfönök I4. század végi pecsétnyomója, a marosvásárhelyi vár régészeti feltárásán került elö

tevékenység ösztönzése. A gyúijtemények digitalizálása érdekében több, a korszerủ követelményeknek megfelelő elektronikus adatbázist készítettünk, amelyek külsős szakemberek számára is kutathatóak. Több ezer tárgyat leltároztunk újra, amelyek a korszerú adatbázisoknak köszönhetóen sokkal könnyebben kutathatók a kereső alkalmazás használatával. A legtöbb tárgy a régészet szakosztályon került leltárba, eddig több mint tízezer leltári számot sikerült bevezetni az adatbázisba. Elkészült a gyújtemények könyvelési érték szerinti újraértékelése, amelyet a számvevőszék igénylésére valamennyi romániai közgyújteménynek 20ı6-ra el kellett végeznie. Ezzel párhuzamosan 2018 végére kell elvégeznük az intézmény újraakkreditációját, amelyet jelenleg a romániai múzeumok mindössze 6-7 százaléka végzett el.

Az újraleltározás lehetôvé tette a gyújteményekkel kapcsolatos kutatások elmélyítését, amely számos szakmai publikációt, tanulmányokat illetve köteteket eredményezett. A Maros Megyei Múzeum kiadásában az elmúlt tíz év alatt több mint száz különböző kiadvány jelent meg: az intézmény évkönyvei mellett számos katalógus, illetve tanulmánykötet. A legjelentősebbek közé sorolnám a Kultúrpalotáról megjelent könyvet és DVD-t, amelyek először mutatják be részletesen a múemlék jelentőségét és építéstörténetét, a Kincses Könyvek sorozatban megjelent Marosvásárhely és Segesvár köteteket, a Vártemplomról megjelent összegző füzetet, a Berecki Sándor és Rezi Botond által gondozott bronzkor- és vaskor-konferencia 
kilenc megjelent kötetét, az Orbán János által gondozott múvészettörténeti tanulmányköteteket, illetve a múvészeti osztály katalógusait. Jelentős eredmény a magyar és a román klasszikus festészetgyúijtemények katalógusa, a Dósa Géza és Vida Árpád marosvásárhelyi festőmúvészekről készült katalógusok, illetve az Elisabeta és Gheorghe David adományát ismertetó katalógus.

A Maros Megyei Múzeum rövid távú célkitúzései közt szerepel a gazdag múemléképület-állományunk felújításának a folytatása és a kiállítások korszerúsítése tartalmi és látványtechnikai szempontból. A Néprajzi Múzeum (Toldalagi-palota) és a várbeli Régészeti és Történeti Múzeum épületének a felújítását sikerült befejezni, a Kultúrpalota és a Természettudományi Múzeum épületei az elnyert EU-s pályázatoknak köszönhetően 202O-ra fognak megújulni. Középtávon szeretnénk befejezni a görgényszentimrei Rákóczi-Bornemissza-kastély, illetve a mezőzáhi Ugron-kastély felújitását, részben önerőből és részben EU-s alapokból. A görgényszentimrei kastély jogi státusa még rendezetlen, ezért jövője sajnos bizonytalan.

Az épületek felújítása mellett nagyon fontos feladat a gyújtemények gyarapítása, új mútárgyak vásárlása. Ennek megfelelően folyamatosan kutatjuk a piacot gyújteményeink kiegészítése érdekében. Elsősorban olyan tárgyakat gyúitünk, amelyek az erdélyi vagy Maros megyei régióhoz köthetők mind történelmi, mind néprajzi szempontból. Szem előtt tartjuk, hogy a kiválasztandó tárgyak legyenek jó minőségúek, legyen egyértelmú a származásuk, ne legyenek esetleg lopott tárgyak. A múvészeti gyújtemény a román, illetve a magyar festőmúvészet, szobrászat kiemelkedő darabjait tartalmazza, ennek megfelelően az újabb szerzemények célja a meglévő gyújtemények kiegészítése, főleg 19-20. századi alkotásokat vásárolunk. Fontos a grafikai, illetve a szobrászati gyúitemény fejlesztése, illetve a helyi vagy országos jelentőségứ, Marosvásárhelyhez köthető múvvészek életmúvének a felvásárlása, a családoknál fellelhető hagyatékok megszerzése. Folyamatosan kutatjuk az egykori neves, mára már szétszóródott Maros megyei gyújtemények darabjait, pl. Teleki Domokos-gyújtemény, Rhédey-gyújtemény, Ugron-gyưjitemény stb., illetve a 20. században aktív és számos jeles múvészt felvonultató marosvásárhelyi festőiskola köréhez tartozó múvészek munkáit (Vida Árpád, Bordi András, Aurel Ciupe, Barabás István, Nagy István, Nagy Imre, Nagy Pál, Olariu Gheorghe, Török Pál stb.) A múzeum gyưijtőtevékenysége kapcsán két katalógus jelent meg, amely a 2005 és 2017 közti gyújtést, vásárlást, régészeti leletmentést tartalmazza, amely révén több ezer jelentős mútárgy került az intézményünk tulajdonába.

$\mathrm{Az}$ intézményfejlesztés része a múzeum kapcsolatrendszerének kiépí- 
tése, amely elsősorban belföldi és magyarországi intézményeket céloz, amelyekkel közös az érdeklődési terület is. Jelenleg Magyarországon a Zala megyei múzeummal alakítottunk ki testvérintézményi kapcsolatot, illetve a pécsi tudományegyetemmel van közös kutatási projektünk, de több közös kiállítást rendeztünk a budapesti Szépmúvészeti Múzeummal, a Magyar Nemzeti Múzeummal. Nagy jelentőségú a székelyföldi múzeumok együttmúködése, közös kiállítási programok lebonyolítása.

Intézményünk nagy hangsúlyt fektet a kutatási programokra, így például a régészeti feltárások bővítésére, elsősorban a jelentős középkori lelőhelyek feltárására, amelyek számos új információt hoznak felszínre, a pontos múemléki és lelőhely-topográfiák elkészítésére. A meglévő listák elavultak és pontatlanok, sokszor hamis információra építenek. A múzeum fejlesztése elengedhetetlen feladat, de legalább ilyen fontos, hogy a pártállam idején kialakult negatív képet megváltoztassuk, és az emberek tudatában ne egy pártpropaganda-intézmény képe éljen, hanem egy meghatározó és közvéleményformáló kultúrintézményként épüljön be a köztudatba. Az új többnyelvú kiállítások és kiadványok a turisztikai vonzerő növekedésében játszanak szerepet, amit a látogatottságon keresztül lehet lemérni. Ehhez a múzeum felhasználja a modern kommunikációs és közönségkapcsolati eszközöket, évente megrendezésre kerül a most már ezreket vonzó múzeumok éjszakája rendezvénysorozat, amely május I7-I8-án kerül megrendezésre, és több ezer embert vonzott a marosvásárhelyi múzeumokba. Ez kiváló alkalom arra, hogy a felnövő nemzedékek megismerjék intézményünket és annak kulturális kínálatát, kiállításainkat és terveinket. A múzeumok éjszakája már nemcsak az intézményünket érinti, hanem marosvásárhelyi rendezvénnyé nőtte ki magát, amelyhez csatlakoztak a Teleki Téka, a Maros Múvészegyüttes, a Nemzeti Színház, a városi állatkert, a Keresztelő Szent János római katolikus plébánia gyújteménye, a Bernády Alapítvány stb.

A Maros Megyei Múzeum középtávú célja, hogy Erdély második legjelentősebb múzeumi pozícióját megerősítse, elérje az évi Ioo ezres látogatói számot, illetve bekapcsolódjon országos múzeumi projektekbe. Egy ilyen kezdeményezés a novemberben nyíló Nicolae Tonitza munkásságát bemutató több, országos jelentőségú intézményt célzó kiállítás, vagy a 2019-re tervezett, az Erdélyi Fejedelemség pénzverését és ötvösmúvészetét bemutató kiállítás. 